1988

\title{
Bright Line Seizures: The Need for Clarity in Determining When Fourth Amendment Activity Begins
}

Edwin J. Butterfoss

Mitchell Hamline School of Law, edwin.butterfoss@mitchellhamline.edu

Publication Information

79 Journal of Criminal Law and Criminology 437 (1988)

\section{Repository Citation}

Butterfoss, Edwin J., "Bright Line Seizures: The Need for Clarity in Determining When Fourth Amendment Activity Begins" (1988).

Faculty Scholarship. Paper 339.

http://open.mitchellhamline.edu/facsch/339 


\title{
Bright Line Seizures: The Need for Clarity in Determining When Fourth Amendment Activity Begins
}

\begin{abstract}
This Article proposes that the Mendenhall-Royer standard, as presently interpreted, should be discarded because it is unworkable and fails to strike the appropriate balance between the liberty interests of citizens and the interest of the state in combatting crime. The test is unworkable because the outcomes of cases turn on subtle factual distinctions unrelated to an individual's actual freedom to end an encounter with a police officer, making it difficult for police officers to apply the standard in the field and adjust their conduct accordingly. Moreover, the standard provides insufficient protection for an individual's rights by failing to consider the purpose of the encounter.

Next, the Article will examine the cases in which the Supreme Court has used the Mendenhall-Royer test. These cases serve as further illustrations both of the difficulty in applying the test and of the lack of guidance the Supreme Court has provided. The Article then will explore the results of this lack of guidance by examining the confusion lower courts are experiencing in deciding cases using the Mendenhall-Royer standard.

Finally, the Article will examine possible alternatives to the Mendenhall-Royer test. It will show that some of these alternatives have been rejected without careful consideration, by overstating the perceived drawbacks to such tests and placing unfounded confidence in the courts' ability to modify' the Mendenhall-Royer test to yield appropriate results. The Article concludes that a per se rule based on the purpose for which a police officer initiates the encounter, although rejected by courts and commentators, is necessary. Such a test provides the appropriate balance between the liberty interest of citizens and the crime fighting interest of the state and is justified by experience with the Mendenhall-Royer test.
\end{abstract}

Keywords

Searches \& seizures (Law)

Disciplines

Criminal Law | Criminal Procedure | Fourth Amendment 


\title{
BRIGHT LINE SEIZURES: THE NEED FOR CLARITY IN DETERMINING WHEN FOURTH AMENDMENT ACTIVITY BEGINS
}

\author{
Edwin J. Butterfoss*
}

\section{INTRODUCTION}

Twenty years ago, in Terry v. Ohio, ${ }^{1}$ the Supreme Court defined a level of police conduct that, although constituting a seizure under the fourth amendment, did not require probable cause on the part of the police. In the course of defining this new level of police conduct, the Court observed that "[o]bviously, not all personal intercourse between police officers and citizens involves 'seizures' of persons. Only when the officer, by means of physical force or show of authority, has in some way restrained the liberty of a citizen may we conclude that a 'seizure' has occurred."2 This observation led to the present framework for analyzing police conduct in which police encounters with citizens are placed into one of three categories: "communication between police and citizens involving no coercion or detention and therefore without the compass of the fourth amendment, brief 'seizures' that must be supported by reasonable suspicion, and full-scale arrests that must be supported by probable cause."3

Because the issue of when a seizure occurred was not decided in Terry, ${ }^{4}$ the precise contours of the "nonseizure" category identified by the Court ${ }^{5}$ were left undefined. Moreover, for more than a dec-

* Associate Professor of Law, Hamline University School of Law; J.D., Georgetown University Law Center, 1980; B.S., Miami University (Ohio), 1977.

1392 U.S. 1 (1968).

2 Id. at 19 n.16.

3 United States v. Berry, 670 F.2d 583, 591 (5th Cir. Unit B 1982).

4392 U.S. at 19. The Court did not decide whether a seizure occurred when Officer McFadden approached Terry to question him because he physically seized Terry.

5 As mentioned above, Chief Justice Warren identified that such a category of police-citizen encounters existed. Justices White and Harlan also discussed a type of police-citizen encounter that would not constitute a seizure under the fourth amendment. Id. at 33, 34 . 
ade following the Terry decision, courts focused on the intermediate category of police conduct: brief seizures. Courts addressed the issue of whether police conduct conceded to be a seizure is justified by sufficiently important governmental interests and defined the limits of that category of police conduct. The "nonseizure" category of police conduct seemed virtually forgotten. Thus, courts did not address the issue of when a citizen has been seized under the fourth amendment. ${ }^{6}$ Finally, in two cases decided at the beginning of this decade, ${ }^{7}$ the Supreme Court focused on the nonseizure category. The court defined the category in a way that permitted significant police activity to be characterized as a nonseizure requiring no objective justification.

In United States v. Mendenhall, ${ }^{8}$ Justice Stewart, in a plurality opinion joined only by Justice Rehnquist, explained that the question of whether an encounter is a brief seizure and not merely a communication involving no coercion or detention should be answered by determining whether a reasonable person would feel free to end the encounter and walk away from the police officer. ${ }^{9}$ If so, no seizure, and thus no fourth amendment activity, has taken place. If not, the citizen has been seized under the fourth amendment, and the police conduct must be tested by the reasonableness requirements of that amendment.

Justice Stewart's test in Mendenhall later was adopted by a majority of the Court in Florida $v$. Royer, ${ }^{10}$ and has been widely accepted by state courts. " State and lower federal courts have applied the

6 See Dix, "Nonarrest Investigatory Detentions in Search and Seizure Law," 1985 Duke L.J. 849, 866-67 (1985); Note, "Reexamining Fourth Amendment Seizures: A New Starting Point," 9 Hofstra L. Rev. 211 , 219-20 (1980).

7 Florida v. Royer, 460 U.S. 491 (1983); United States v. Mendenhall, 446 U.S. 544 (1980).

8446 U.S. 544 (1980).

$9 \mathrm{Id}$. at 554. "Walk away" is appropriate terminology because the encounters in question virtually always occur between an officer and a pedestrian. Unlike these pedestrian cases, the Court views virtually any encounter between a police officer and the operator of an automobile as a seizure. The divergent treatment of these encounters is not easily explained and is a weakness of the Mendenhall-Royer test for determining when a seizure has occurred. But see United States v. Mendenhall, 446 U.S. at 556-57 ("stopping or diverting an automobile in transit, with the ... opportunity for a visual inspection of . . . passenger compartment, ... is materially more intrusive than a question ... to a passing pedestrian."). Contra United States v. Adegbite, $43 \mathrm{Cr}$. L. Rptr. (BNA) 2181 (2d Cir. May 13, 1988)(plainclothes officers waving arms to flag down moving truck in parking lot, identifying themselves, and asking for identification not a seizure).

10460 U.S. 491 (1983).

11 Richardson v. United States, 520 A.2d 692 (D.C. 1987); Pastor v. State, 498 So. 2d 962 (Fla. Dist. Ct. App. 1986); Goodman v. State, 180 Ga. App. 347, 349 S.E.2d 216 (Ga. Ct. App. 1986); State v. Harlan, 301 N.W.2d 717 (Iowa 1981); State v. Jones, 495 So. 2d 334 (La. Ct. App. 1986); State v. Davis, 517 A.2d 863 (N.J. 1986); State v. 
test to define a broad spectrum of police conduct involving approaching and questioning citizens as "nonseizures." This is ironic because it is generally accepted that, in fact, citizens almost never feel free to end an encounter initiated by a police officer and walk away. ${ }^{12}$ Thus, literal application of the Mendenhall-Royer "free-toleave" test would result in virtually all police-citizen encounters being characterized as seizures and thereby eliminate the "nonseizure" category of such encounters.

Nevertheless, the test has not been applied-nor was it intended to be applied ${ }^{13}$ _in such a manner. Rather, as stated above, precisely the opposite has occurred. Application of the test has created a broad "nonseizure" category of police-citizen encounters that permits officers substantial leeway in approaching and questioning citizens without being required to show objective justification for such conduct. This has been accomplished both by constructing a highly artificial "reasonable person," who is much more assertive in encounters with police officers than is the average citizen, and by ignoring the subjective intentions of the officer. The result is that fourth amendment rights of citizens are determined through a legal fiction. ${ }^{14}$ In many encounters with citizens, police conduct is not scrutinized under the fourth amendment because in the courts' view a reasonable person would feel free to end the encounter and walk away. However, given the reality that citizens virtually never feel free to walk away from an encounter initiated by a police officer, ${ }^{15}$ most of the citizens in these "nonseizure" encounters do not feel free to walk away. Moreover, in a significant number of these "nonseizure" cases, the police officers involved tes-

Thomas, 343 S.E.2d 591 (N.C. Ct. App. 1986); Russell v. State, 717 S.W.2d 7 (Tex. Crim. App. 1986); State v. Belanger, 677 P.2d 781 (Wash. Ct. App. 1984).

12 See United States v. Cordell, 723 F.2d 1283 (7th Cir. 1983); United States v. Barnes, 496 A.2d 1040 (D.C. 1985); Williamson, "The Dimensions of Seizure: The Concepts of 'Stop' and 'Arrest'," 43 OHio St. L.J. 771, 801 (1982); 3 W. LAFAvE, SEARch and Seizure: A Treatise on the Fourth Amendment, \$ 9.2(h) at 402 (1987) [hereinafter LaFave, Search and SEIzure]; LaFave, "Fourth Amendment Vagaries (of Improbable Cause, Imperceptible Plain View, Notorious Privacy, and Balancing Askew)," $74 \mathrm{~J}$. Crim. L. \& Criminology 1171, 1185 (1983)[hereinafter, LaFave, "Fourth Amendment Vagaries"]; Model Code of Pre-Arraignment Procedure § 110.1, comment at 258 (1975).

13 This is obvious given that Justice Stewart, the author of the test, used it to find that Sylvia Mendenhall was not seized when she was approached by police officers and questioned.

14 Williamson, supra note 12 , at 814 ("[T] of inquiry, at least in some cases, to the perception rather than the fact of a restriction on freedom of movement."); United States v. Cordell, 723 F.2d 1283 (7th Cir. 1983).

15 See supra note 12. 
tified that the citizen in fact was not free to leave. ${ }^{16}$ The result is that citizens who do not feel free to end encounters with police and who, in fact, would not be permitted to do so, are left outside the scope of fourth amendment protections because the reasonable person constructed by the courts would have felt free to leave.

Lack of judicial scrutiny of these encounters is troubling because often the purpose of the encounters is to obtain either a confession or the individual's consent to a search. ${ }^{17}$ Many of the encounters are successful and citizens are convicted for crimes with evidence obtained through their "voluntary" cooperation with a police officer during an encounter that the officer had no objective reason to initiate and for which the court requires no explanation. Moreover, in many instances the facts of these "voluntary cooperation nonseizure" cases resulting in convictions are strikingly similar to those cases in which confessions or evidence gained from "consent" searches are suppressed based on unlawful police conduct in initiating the encounter. ${ }^{18}$

These inconsistent outcomes result in part from the artificiality of the test applied by the courts. Because the seizure-nonseizure decision is not based on a realistic appraisal of the individual's freedom to walk away, but rather on an artificial reasonable person standard, ${ }^{19}$ the outcomes turn on "minute factual differences" 20 that courts have determined to be crucial, but which bear little relationship to the individual's actual freedom to walk away. This artificial-

16 See United States v. Mendenhall, 446 U.S. 544,575 n.12 (1980); United States v, Woods, 720 F.2d 1022, 1025 (9th Cir. 1983); State v. Shy, 373 So. 2d 145, 149 (La. 1979); State v. Ferola, 518 A.2d 1339, 1343 (R.I. 1986).

17 See Greenberg, "Drug Courier Profiles, Mendenhall and Reid: Analyzing Police Intrusions on Less Than Probable Cause," 19 Am. Crim. L. Rev. 49, 75 (198I)("In [drug cases] a limited stop based on less than probable cause is of little investigative value without extensive subsequent intrusions."); Williamson, supra note 12, at 773-74 (" $[S]$ eizure of an individual may provide the opportunity to question the person and obtain incriminating statements ... [and] . . other evidence ...."); Note, "Reformulating Seizures-Airport Stops and the Fourth Amendment," 69 Calif. L. Rev. 1486, 1488 (1981)(The purpose of questioning by agents in airport offices or similar locations "is to obtain permission to search the suspect's person and luggage for narcotics.") [hereinafter, Note, "Reformulating Seizures"].

18 United States v. Berry, 670 F.2d 583, 588-89 (5th Cir. Unit B 1982); United States v. Patino, 649 F.2d 724, 728 (9th Cir. 1981); Becton, "The Drug Courier Profile: "All Seems Infected That Th' Infected Spy, As All Looks Yellow to the Jaundic'd Eye'," 65 N.C.L. REv. 417, 454 (1987); Note, "Reformulating Seizures," supra note 17, at 1492 n.40, 1499 n.78.

19 See United States v. Cordell, 723 F.2d 1283, 1286 (7th Cir. 1983)(Mendenhall-Royer test makes decision depend on "technical legal construct" rather than a factual inquiry); United States v. Barnes, 496 A.2d 1040, 1044 n.9 (D.C. 1985)(Mendenhall-Royer test arbitrary, based on practical policy decision to expand options of police).

20 United States v. Berry, 670 F.2d 583 (5th Cir. Unit B 1982). 
ity has resulted in a category of nonseizures that bears little resemblance to encounters initiated by police for purposes "wholly unrelated to a desire to prosecute for crime"21 described in Justice Warren's opinion for the Court in Terry.

Courts have lost sight of Justice Warren's observation that "street encounters between citizens and police officers are incredibly rich in diversity"22 and concern themselves not with the purpose of the encounter, but only with the effect of the officers' actions on the reasonable person they have constructed. Courts have justified their expansion of the nonseizure category of police-citizen encounters by relying on the duty of every citizen to cooperate with police, even when the cooperation sought by the police is cooperation implicating the individual herself in criminal activity. ${ }^{23}$ The artificiality results because the reasonable person standard masks a policy choice concerning the value or appropriateness of police seeking cooperation from suspects. Utilizing the Mendenhall-Royer "free to leave" test, courts have greatly expanded the category of nonseizures by ignoring the fifth amendment implications of encounters involving an individual suspected of criminal activity.

Although the Mendenhall-Royer test has been criticized, ${ }^{24}$ commentators are surprisingly hesitant to advocate its abandonment. ${ }^{25}$ Moreover, even those in favor of replacing the test resist doing so

21 Terry, 392 U.S. at 13.

22 Id. at 13; see also United States v. Berryman, 717 F.2d 651, rev'd, 717 F.2d 650 (1st Cir. 1983) (en banc).

23 The duty of every citizen to cooperate with police offices in the detection and prevention of crime has long been recognized. In Miranda v. Arizona, the Court noted that "[i] $\mathrm{t}$ is an act of responsible citizenship for individuals to give whatever information they may have in the aid of law enforcement." 384 U.S. 436, 477-78 (1966). Similarly, in Coolidge v. New Hampshire, 403 U.S. 443, 488 (1971), the Court, in a plurality opinion, stated that "[i]t is no part of the policy of the fourth and fourteenth amendments to discourage citizens from aiding to the utmost of their ability in the apprehension of criminals."

Of course, it is part of the fifth amendment that such a duty does not include a responsibility to aid law enforcement by confessing to one's own criminal actions. Nevertheless, the duty of citizens to cooperate seems to have influenced recent decisions in which police officers seek the cooperation of individuals not to apprehend others, but to gain incriminating evidence against the individual himself. Moreover, the Court seems to have changed its view of the value of evidence gained from a suspect or an accused and has begun to place considerable value on such evidence. See Van Kessel, "The Suspect as a Source of Testimonial Evidence: A Comparison of the English and American Approaches," 38 Hastings L.J. I, 6 (1986).

24 See Note, "Reformulating Seizures," supra note 17, at 1495-1502; Becton, supra note 18, at 467-69; Greenberg, supra note 17, at 68-72; LAFAve, SEARCh ANd Seizure, supra note 12 , at $411-412$.

25 LAFAVE, SEARch AND SEIzuRE, supra note 12, at 411 (suggesting appropriate way to "interpret" Mendenhall-Royer test); Dix, supra note 6, at 867 (Mendenhall-Royer standard might well be the only appropriate and feasible one). 
with a per se rule based upon the purpose of the officer in initiating the encounter. ${ }^{26}$ This Article proposes that the Mendenhall-Royer standard, as presently interpreted, should be discarded because it is unworkable and fails to strike the appropriate balance between the liberty interests of citizens and the interest of the state in combatting crime. The test is unworkable because the outcomes of cases turn on subtle factual distinctions unrelated to an individual's actual freedom to end an encounter with a police officer, making it difficult for police officers to apply the standard in the field and adjust their conduct accordingly. Moreover, the standard provides insufficient protection for an individual's rights by failing to consider the purpose of the encounter.

The test should be replaced by a per se rule based on the purpose for which the officer initiates the encounter with the citizen. If a police officer initiates contact with an individual to investigate that individual for complicity in criminal activity, the officer should be required to demonstrate an objective basis-reasonable suspicionfor doing so. Such a standard is easily applied and strikes the proper balance between the protection required for citizens and the need to avoid burdening police unnecessarily. Although such a test is unlikely to be adopted by the present Supreme Court, it is a standard that state courts should consider in analyzing encounters between police and citizens of the state. ${ }^{27}$

This Article will first examine the two cases in which the present test was developed. ${ }^{28}$ This examination will show that Justice Stewart developed the test with virtually no analysis of why it is the appropriate means to determine when a citizen has been seized by a police officer and that a majority of the Court later adopted the test with a similar lack of analysis. Moreover, the inconsistent results in these two cases illustrate the difficulty in applying the test. Next, the Article will examine the cases in which the Supreme Court has used the Mendenhall-Royer test. ${ }^{29}$ These cases serve as further illustrations both of the difficulty in applying the test and of the lack of guidance

26 Note, "Reformulating Seizures," supra note 17, at 1502-03 (proposing a "multifactor analysis"); Becton, supra note 18, at $471-72$ (proposing bright line rule for drug courier profile stops); Greenberg, supra note 17, at 76 (proposing prophylactic rule requiring warnings of right to refuse consent to search); Comment, "Fourth Amendment Airport Searches and Seizures: Where Will the Court Land?" 71 J. CRIM. L. \& CRIMINOLOGY 499, 512 (1980)(proposing "hindsight" rule classifying as seizures encounters where incriminating evidence is found).

27 Michigan v. Chesternut, 43 Crim. L. Rptr. (BNA) 3077 (U.S. S. Ct. June 13, 1988)(refusing to adopt bright line test to determine when seizure occurs in chase cases).

28 See infra text accompanying notes 33-85.

29) See infra text accompanying notes 86-105. 
the Supreme Court has provided. The Article then will explore the results of this lack of guidance by examining the confusion lower courts are experiencing in deciding cases using the Mendenhall-Royer standard. ${ }^{30}$ Some lower courts interpret the Supreme Court decisions to mean that in the absence of an explicit show of authority or threat of force, a reasonable person feels free to walk away from an encounter initiated by a police officer. Therefore, the person has not been seized, regardless of the officer's reasons for initiating the encounter. These courts narrowly apply the Mendenhall-Royer standard to create a broad category of police conduct which falls below the level of a seizure. Other courts are less willing to accept that a reasonable person would feel free to walk away from an encounter with a police officer that goes much beyond a simple request to talk. These courts find a seizure has occurred at varying points during police-citizen encounters. These different interpretations result in vastly different treatment of factually similar cases.

Finally, the Article will examine possible alternatives to the Mendenhall-Royer test. ${ }^{31}$ It will show that some of these alternatives have been rejected without careful consideration, by overstating the perceived drawbacks to such tests and placing unfounded confidence in the courts' ability to modify, the Mendenhall-Royer test to yield appropriate results. The Article concludes that a per se rule based on the purpose for which a police officer initiates the encounter, although rejected by courts and commentators, is necessary. Such a test provides the appropriate balance between the liberty interest of citizens and the crime fighting interest of the state and is justified by experience with the Mendenhall-Royer test. ${ }^{32}$

\section{The MENDENHALL-ROYER Standard}

The present standard for determining whether a police-citizen encounter constitutes a seizure first appeared in the lead opinion in United States v. Mendenhall. ${ }^{33}$ In Mendenhall, defendant Sylvia Mendenhall was observed by two Drug Enforcement Agency agents at the Detroit Metro Airport as she disembarked from an airplane arriving from Los Angeles. Because the agents believed Ms. Mendenhall's conduct to be characteristic of persons unlawfully carrying narcotics, ${ }^{34}$ the agents approached her as she was walking through

30 See infra text accompanying notes 106-40.

31 See infra text accompanying notes 141-79.

32 See infra text accompanying notes 181-228.

33446 U.S. 544 (1980).

34 The agent testified that Ms. Mendenhall's behavior fit the "drug courier profile." Id. at 547 n.1. 
the concourse, identified themselves as federal agents, and asked to see her identification and airline ticket. Ms. Mendenhall produced a driver's license in the name of Sylvia Mendenhall and an airline ticket issued to "Annette Ford." Asked to explain the discrepancy, Mendenhall stated that she "just felt like using that name." 35 In response to a further question, Mendenhall stated she had been in California only two days. At that point, one of the agents specifically identified himself as a narcotics agent, and Mendenhall became "quite shaken [and] extremely nervous."36 The agents returned Mendenhall's license and ticket and requested that she accompany them to the airport DEA office for further questioning. Without orally responding, Mendenhall followed the agents to the office. ${ }^{37}$ Once there, Mendenhall agreed to a search of her person and her handbag, although she was informed that she had the right to decline. The subsequent search led to the discovery of heroin, and Mendenhall was arrested. ${ }^{38}$

Justice Stewart's lead opinion in Mendenhall focused on whether Mendenhall had been "seized" when the agents approached her on the concourse and asked her questions. ${ }^{39}$ If she had, the agents were required to provide an objective justification for their conduct. That is, they were required to show that they reasonably suspected Mendenhall of wrongdoing. ${ }^{40}$ Conversely, if Mendenhall was not seized, no objective justification was required because without a seizure there was no "foundation whatever for invoking constitutional safeguards." 41

Justice Stewart started from the premise articulated by Justice Warren in Terry $v$. Ohio that not all encounters between police and citizens constitute seizures. Quoting the concurring opinions of Justices White and Harlan in Terry, Justice Stewart explained that " " $[t]$ here is nothing in the Constitution which prevents a policeman from addressing questions to anyone on the street," " and that

In this case, the agents thought it relevant that (1) the respondent was arriving on a flight from Los Angeles, a city believed by the agents to be the place of origin for much of the heroin brought to Detroit; (2) the respondent was the last person to leave the plane, 'appeared to be very nervous,' and 'completely scanned the whole areas where [the agents] were standing'; (3) after leaving the plane the respondent proceeded past the baggage area without claiming any luggage; and (4) the respondent changed airlines for her flight out of Detroit.

Id. at 547 n. 1 .

35 Id. at 548.

36 Id.

37 Id.

38 Id. at 549-50.

39 Id. at 551 .

40 Id. at 552.

41 Id. at 553 (citations omitted). 
"[p]olice officers enjoy 'the liberty (again, possessed by every citizen) to address questions to other persons,' although 'ordinarily the person addressed has an equal right to ignore his interrogator and walk away." "42 In Justice Stewart's view,43 precedent demonstrated that only when this liberty was "in some way demonstrably curtailed" was a seizure effectuated requiring objective justification. ${ }^{\mathbf{4 4}}$ Thus, Justice Stewart "adhere[d] to the view [expressed in Terry] that a person is 'seized' only when, by means of physical force or a show of authority, his freedom of movement is restrained."45 Justice Stewart explained that no seizure occurs "[a]s long as the person to whom questions are put remains free to disregard the questions and walk away." 46 The converse of this is that when the person is not free to disregard the questions and walk away, a seizure has occurred. Thus, under a literal interpretation of this definition of seizure, when an individual in fact is not free to walk away because the officer has no intention of letting the individual go, a seizure has occurred. ${ }^{47}$ A single paragraph later in his Mendenhall opinion, however, Justice Stewart offered a less inclusive definition of a seizure. ${ }^{48}$ Justice Stewart stated that "[w]e conclude that a person has been 'seized' within the meaning of the Fourth Amendment only if, in view of all the circumstances surrounding the incident, a reasonable person would have believed that he was not free to leave." 49

$42 \mathrm{Id}$. (quoting the concurring opinions of $\mathrm{Mr}$. Justice White and Mr. Justice Harlan in Terry v. Ohio, 392 U.S. 1, 34, 31-33 (1968)).

43 Id. at 553.

44 Id. Stewart believed this was demonstrated by Sibron v. New York, 392 U.S. 40 (1968), a companion case to Terry. In Sibron, a police officer approached the defendant in a restaurant, told him to come outside, and searched him when he did so. The Court explained that, in light of the subsequent search, it was not necessary to decide whether Sibron was seized inside the restaurant. The Court noted that the record was unclear with respect to what occurred in the restaurant, and was "totally barren of any indication whether Sibron accompanied [the officer] outside in submission to a show of force or authority which left him no choice, or whether he went voluntarily in a spirit of apparent cooperation with the officer's investigation." Id. at 63. Although the Sibron court explained that "this deficiency in the record is immaterial" in light of the subsequent illegal search, Justice Stewart felt that the quoted language demonstrated that "[p]lainly ... there was no seizure until the police officer in some way demonstrably curtailed Sibron's liberty." Id. at 553 .

45 Id. at 554.

46 The person has stopped to talk to a police officer and the officer will not let the person leave. Thus, "his freedom of movement is restrained."

47 See Williamson, supra note 12, at 814 ("[T] clearly directs the focus of inquiry, at least in some cases, to the perception rather than the fact of restriction on freedom of movement.").

48446 U.S. at 554.

49 Id. 
The factors to be considered in reaching this determination included the number of officers present, the display of a weapon, physical contact between the officer and citizen, and the officer's language and tone of voice. ${ }^{50}$ On the facts of the case before the Court, Justice Stewart concluded that no seizure had occurred. Important in the Mendenhall decision were the facts that the events took place on a public concourse, the agents were not in uniform and did not display weapons, and the officers did not summon the defendant but rather approached the defendant and identified themselves as federal agents and requested, but did not demand, to see defendant's identification and airline ticket. ${ }^{51}$ Justice Stewart made clear that " $[t]$ he respondent was not seized simply by reason of the fact that the agents approached her, asked her if she would show them her ticket and identification, and posed to her a few questions."52 With a questionable citation to the ALI Model Code of Pre-ARRaignment Procedures ${ }^{53}$, Justice Stewart stated that a law enforcement officer's questioning an individual is not enough to establish a seizure. ${ }^{54}$ Justice Stewart concluded that "[i]n short, nothing in the record suggests that the respondent had any objective reason to believe that she was not free to end the conversation in the concourse and proceed on her way ...."55 The fact that the officer had testified that Mendenhall was not free to walk away did not concern Justice Stewart. He made clear in a footnote that under this definition of seizure, the subjective intention of the officer or agent in detaining a suspect is irrelevant except insofar as that may be conveyed to the citizen. ${ }^{56}$ Justice Stewart offered no explanation of why a focus on the belief of a reasonable person was more appropriate than an assessment of whether the suspect actually was free to leave. The latter assessment seemed mandated by the earlier definition of seizure quoted from Terry and could easily have been made in the

$50 \mathrm{Id}$.

51 Id. at 555 .

52 Id.

53 Model Code of Pre-Arraignment Procedure $\S 110.1$, Comment at 258 (1975).

54 Mendenhall, 446 U.S. at 555. This citation by Justice Stewart is misleading because although the Model Code section he cited (Sec. 101.1(1)) permits officers to approach and request cooperation from citizens without effecting a seizure, it does not extend this authority to encounters with individuals suspected of criminal activity. In that case, the Code requires that warnings be given to the individual. Thus, Justice Stewart's citation to Sec. 101.1(1) to support the authority of an officer to approach and question an individual suspected of a crime is simply wrong. He is not alone, however, in seeking support for police encounters with suspects in this section. See LAFAvE, SEARCH AND Seizure, supra note 12, at 412 n.242.

55 Mendenhall, 446 U.S. at 555.

$56 I d$. at 554 n.6. 


\section{case before the Court. ${ }^{57}$}

The remaining opinions in Mendenhall did not address the seizure issue in detail. In his concurrence, Justice Powell assumed that a seizure had taken place but thought reasonable suspicion existed to justify it. $58 \mathrm{He}$ did not "necessarily disagree" with the standard set forth by Justice Stewart, but thought the question of whether Mendenhall reasonably could have thought she was free to "walk away" was extremely close. 59 In his dissenting opinion, Justice White likewise assumed a seizure had occurred, but he seemed to disagree with the standard suggested by Stewart, at least as it was being applied in the present case. 60

The presence of three separate analyses of the police-citizen encounter in Mendenhall understandably led to some uncertainty among lower courts as to what standard to use in determining if a seizure had occurred. ${ }^{61}$ That uncertainty was removed, however, in Florida v. Royer ${ }^{62}$ In Royer, a four justice plurality, in an opinion authored by Justice White, adopted the "reasonable person-free to leave" test of Mendenhall to find that the defendant had been seized.63 In addition, Justice Blackmun, although dissenting, expressly concurred in the plurality's adoption of the Mendenhall standard. 64

Royer was an "airport 'stop for questioning' case similar in its general setting" to Mendenhall. ${ }^{65}$ Royer was observed at Miami International Airport by two plainclothes detectives who believed Royer's conduct to be characteristic of persons unlawfully carrying narcotics. ${ }^{66}$ On the concourse leading to the boarding area, the two

57 The officer had testified that Mendenhall was not free to leave. Id. at $575 \mathrm{n} .12$ (White, J., dissenting).

58446 U.S. at 560 (Powell, J., concurring in part and concurring in judgment).

59 Id. at 560 n.1.

60 Id. at 569-71 (White, J., dissenting). See also Williamson, supra note 12, at 784 (it is unclear whether Justice White's criticism of Justice Stewart's opinion was "for purposes of demonstrating that the 'reasonable man' standard should not be controlling, or merely for purposes of demonstrating the analytical weakness of the Stewart opinion in Mendenhall.").

61 Becton, supra note 18, at 463 ("Immediately after Mendenhall and Reid confusion abounded among lower courts.");

62460 U.S. 491 (1983).

63 Id. at 502 ("These circumstances surely amount to a show of official authority such that a 'reasonable person would have believed that he was not free to leave." ")

$64 I d$. at 514 . The three remaining dissenters, in an opinion written by Justice Rehnquist, who originally joined with Stewart in the lead opinion in Mendenhall setting forth the "reasonable person" standard, also seemed to agree that the Mendenhall standard was the correct one. Id. at 523 n.3.

$65 \mathrm{Id}$. at 508 (Powell, J., concurring).

66 They believed his appearance, mannerisms, luggage, and actions fit the so-called drug courier profile. Id. at 493. In Royer's case: 
detectives approached Royer, identified themselves as police officers, and asked if Royer had a moment to speak with them. Royer said "yes." The officer requested, and Royer produced, his airline ticket bearing the name "Holt" and a driver's license in the name of Royer. When asked about the discrepancy, Royer explained that a friend had made the reservation in the name of "Holt." According to the officers, Royer became noticeably more nervous during this conversation. The officers informed Royer that they were narcotics investigators and that they had reason to suspect him of transporting narcotics. ${ }^{67}$

Without returning his ticket (a fact which turned out to be crucial), ${ }^{68}$ the officers asked Royer to accompany them to the adjacent concourse approximately 40 feet away. Without responding, Royer went with the officers to a room located in the flight attendants' lounge which contained a small desk and two chairs. Royer's luggage was retrieved from the airline without his consent and brought to the room. In response to a request for consent to search the luggage, Royer produced a key to one suitcase and permitted the officers to pry open the other one. Marijuana was found, and Royer was arrested. Approximately fifteen minutes had elapsed from the time the detectives initially approached Royer until his arrest. ${ }^{69}$

In a plurality opinion joined by three other justices, Justice White held the searches of the luggage unlawful because at the time of the search Royer, "as a practical matter," was under arrest, ${ }^{70}$ and probable cause did not exist to justify such an arrest. ${ }^{71}$ Preliminary to this holding, the plurality rejected as untenable the state's argument that the entire transaction was consensual, finding that at an early point in the encounter the officers had seized Royer. ${ }^{72}$ Although conceding that asking for and examining Royer's ticket was permissible, the plurality explained:

[W] hen the officers identified themselves as narcotics agents, told

the detectives attention was attracted by the following facts which were considered to be within the profile: (a) Royer was carrying American Tourister luggage, which appeared to be heavy, (b) he was young, apparently between 25-35, (c) he was casually dressed, (d) he appeared pale and nervous, looking around at other people, (e) he paid for his ticket in cash with a large number of bills, and ( $f$ ) rather than completing the airline identification tag to be attached to checked baggage, which had space for a name, address, and telephone number, he wrote only a name and the destination.

Id. at 493 n.2.

67 Id. at 494.

68 See infra discussion at notes 74-77. See also Royer, 460 U.S. at 503-04 n.9.

69460 U.S. at $494-95$.

$70 \mathrm{Id}$. at 503 .

$71 \mathrm{Id}$. at 507 .

$72 \mathrm{Id}$. at 501 . 
Royer that he was suspected of transporting narcotics, and asked him to accompany them to the police room, while retaining his ticket and driver's license and without indicating in any way that he was free to depart, Royer was effectively seized for purposes of the Fourth Amendment. ${ }^{73}$

The Court decided this because " $[\mathrm{t}] \mathrm{h}$ ese circumstances surely amount to a show of official authority such that a 'reasonable person would have believed that he was not free to leave." "74 Why these circumstances "surely" amounted to a show of authority such that a reasonable person would not feel free to leave while the similar circumstances in Mendenhall did not is not at all clear. The only difference in this litany of factors is the retention of the license and ticket. ${ }^{75}$ Apparently Justice White felt comfortable having important fourth amendment rights turn on what would seem a minor fact because "[a]s a practical matter, Royer could not leave the airport without them."76 Of course, Mendenhall, as a practical matter, also could not have left the airport, because a) she didn't believe she was free to leave and b) the officer would not have permitted her to leave. The Court's struggle to reconcile the seizure determination and the split of the Justices as to the correct characterization of these encounters demonstrates the difficulty of accurately characterizing police-citizen encounters under the Mendenhall-Royer test.

Perhaps because Royer ultimately prevailed in the case, absent from Justice White's opinion was his earlier apparent discomfort with the "free to leave" standard. Also absent-again perhaps because the seizure issue was not crucial to the outcome of the case 77 -was any analysis of why the "free to leave" test was the appropriate one to answer the question of whether "the officer, by means of physical force or show of authority, [had] in some way restrained the liberty of a citizen ...."78 The Supreme Court has never explained its use of the test to answer that question. ${ }^{79}$ An

73 Id.

74 Id. at 502.

75 Id. at 503.04 n.9.

$76 \mathrm{Id}$. Of course, Justice White also thought a seizure had occurred in Mendenhall. Nevertheless, he took great pains to distinguish that case from the one before the court, perhaps for the benefit (or vote) of Justice Stewart who joined White's opinion in Royer but had authored the opinion finding no seizure in Mendenhall. See also id. at 508 (Powell, J., concurring).

77 The seizure issue of itself was not crucial because the plurality believed there was reasonable suspicion to justify such a seizure. The question was whether the police had exceeded the bounds of a Terry stop and, if so, whether they had probable cause to do so. Id. at 502 .

78460 U.S. at 523 n.3.

79 Williamson, supra note 12 , at 814 . ("The nuances of [the reasonable person test] never have been explored fully by the courts ...."). 
explanation is called for, however, because in fact the 'free to leave' test does not accurately measure whether a citizen's liberty has been in some way restrained. As mentioned earlier, it is generally recognized that most citizens do not feel free to walk away from a police officer who approaches to ask them questions. ${ }^{80}$ Thus, in a literal sense, the citizen's liberty "has in some way been restrained." 81 Moreover, in many cases the citizen's liberty has been restrained in a very real sense because, in fact, the officer does not intend to let the citizen continue on their way if they assert their right to do so. ${ }^{82}$ Thus, the Mendenhall-Royer test is underinclusive to the extent it does not include these classes of cases within the definition of seizure. Moreover, it is clear that the Mendenhall-Royer test is not intended to characterize every encounter in which either of these situations exist as a seizure. The encounter in Mendenhall itself was found not to be a seizure by the author of the standard although it clearly falls into the category where most commentators agree that an average citizen would not feel free to end the encounter. ${ }^{83}$ Moreover, Justice Stewart expressly stated in Mendenhall that the subjective intention of the officer to detain the suspect is irrelevant, thus excluding from the category of seizure at least some cases where in fact the citizen is not free to leave. ${ }^{84}$

The underinclusiveness of the Mendenhall-Royer standard has not led commentators to call for discarding the test. In large part, this seems to be based on a perception that other alternatives are unworkable and the Mendenhall-Royer test can be interpreted in such a way as to strike the appropriate balance between the law enforcement needs of the state and the liberty right of citizens. ${ }^{85}$ However, as explained below, often the perceived drawbacks to alternative tests are overstated and the weaknesses of the present test are ignored. Thus, there exists an inflated view of the superiority of the

80 See supra note 12 and accompanying text.

81 Williamson, supra note 12, at 790 ("If an individual subjectively believes that he or she has been deprived of his or her freedom of movement under the guise of official authority and submits, the deprivation is complete.").

82 See supra note 16 and accompanying text.

83 As explained above, most commentators believe citizens never feel free to leave when approached and questioned by a police officer. Moreover, the similarity of Mendenhall to Royer where an arrest was found, indicates it is unlikely that Sylvia Mendenhall realistically felt free to leave.

84 Only some cases of this type are excluded because if the officer communicates his intentions to the suspect, a seizure has occurred under the Mendenhall-Royer standard.

85 See Dix, supra note 6, at 867, 870 ("The Mendenhall-Royer standard might well be the only appropriate and feasible one"; "the standard might, however, be applied as a matter of state law in a manner different than was suggested in Delgado."); Williamson, supra note 12, at 787-90; Note, supra note 6, at 229-31. 
Mendenhall-Royer test. Moreover, courts apply the test in a fashion that creates an overly broad "nonseizure" category of police-citizen encounters, thus failing to adequately protect the liberty interests of citizens.

\section{ApPLiCATION OF THE MENDENHALL-ROYER Test}

\section{A. SUPREME COURT DECISIONS}

The divergent results, despite similar facts, of the two Supreme Court cases that formulated the Mendenhall-Royer test are indicative of the difficulty in applying the test. The only factual difference between the two cases at the point the plurality found Royer was seized was the retention of Royer's airline ticket and identification. Yet the results are vastly different. Justice Stewart did not even find that Mendenhall had been seized during her ordeal, while the plurality found that Royer was not only seized, but also arrested. ${ }^{86}$ Moreover, in finding a seizure of Royer, the plurality pointed to facts that also were present in Mendenhall. ${ }^{87}$ The Court's cases following Mendenhall and Royer provide no further elucidation. In Reid v. Georgia, ${ }^{88}$ again on facts "remarkably similar" 89 to Mendenhall, the

86 Although at the point in the encounter that the plurality found Royer was "for all practical purposes under arrest" there were additional factual differences-Royer was taken to a room described as a closet as opposed to the larger room in Mendenhall and Royer's luggage had been retrieved without his consent-it is unlikely these facts would have been sufficient to escalate the encounter into an arrest if the plurality had characterized the encounter at that point, like Mendenhall's, as consensual. Conversely, if Mendenhall's early contact with the police was characterized a seizure, her detention, even in a large room, would have likely amounted to an arrest. Thus, the different treatment of the cases resulted from the differing characterization of the early encounter, which apparently was based on the single factual difference mentioned above-the retention of Royer's identification and airline ticket.

The divergent results demonstrate a collateral effect of expanding the "nonseizure" category through the application of the Mendenhall-Royer test. The middle category in the analysis, brief "seizures" that must be supported by reasonable suspicion, in some respects seems to be disappearing. This is because the level of intrusiveness required before a seizure is found is so high, that it is very similar to conduct that requires a finding of an arrest. See United States v. Ceballos, 812 F.2d 42 (2d Cir. 1987)(lower court found entire encounter non-seizure until point of arrest; appellate court finds seizure at earlier point); State v. Jones, 495 So, 2d 334 (La. Ct. App. 1986)(lower court found co-defendant was arrested; appellate court finds no seizure under Mendenhall); State v. Ferola, 518 A.2d 1339 (R.I. 1986)(applying "free to leave" test to determine whether suspect arrested).

87 The plurality emphasized that the officers identified themselves as narcotics agents, informed the suspect of their suspicions, asked him to accompany them to the police room, and failed to inform him that he was free to depart, all facts that were also present in Mendenhall. 446 U.S. 544, 547-48. This apparent discrepancy has led one court to read Royer as limiting Mendenhall to its facts. See United States v. Saperstein, 723 F.2d 1221, 1225 (6th Cir. 1983).

88448 U.S. 438 (1979). 
Court avoided the seizure issue and remanded to the state appellate court. ${ }^{90}$ In a later case, Florida v. Rodriguez, ${ }^{91}$ the Court only partially addressed the seizure issue.

In Rodriguez, a Dade County Public Safety Department officer assigned to the airport unit noticed Rodriguez at the National Airlines ticket counter in the Miami airport. Suspicious of the "unusual manner" in which Rodriguez and two companions left the counter, the officer and his fellow officer followed the trio. While riding an escalator in the airport concourse, Rodriguez' companions made eye contact with the police officers twice and spoke to each other in low voices. As they exited the escalator, one of the companions twice exhorted Rodriguez to "get out of here." At that point, Rodriguez caught sight of the detectives and unsuccessfully attempted to leave. 92 "His legs were pumping up and down very fast and not covering much ground, but his legs were as if the person were running in place." 93 Rodriguez then confronted the officer and uttered a vulgar exclamation. In the face of this conduct, the officer "showed his badge and asked [Rodriguez] if they might talk. [Rodriguez] agreed, and [the officer] suggested that they move approximately fifteen feet to where [his companions] were standing with [the other officer] ...."94 In the discussion that followed, Rodriguez, prompted by one of his companions, provided a key to a suit

89 Id. at 443 (Powell, J. concurring).

90 In Reid, the defendant and a companion were approached outside the Atlanta airport terminal by a DEA agent who suspected them of carrying narcotics. The agent identified himself as a federal narcotics agent and asked Reid and his companion to show him their airline tickets and identification, which they did. The agent asked if they would agree to return to the terminal and consent to a search of their persons and their bags. The agent testified that the pair agreed. As the suspects and the agent entered the terminal, the defendant began to run. Before he was apprehended, he abandoned his shoulder bag. The bag was recovered and found to contain cocaine. Id. at 439 . Reid was arrested. The Georgia Court of Appeals reversed the trial court's suppression of the cocaine, holding that the stop of the defendant was permissible under Terry because defendant's fit with the drug courier profile provided the necessary reasonable suspicion. Id. at 440-41. The Supreme Court, in a per curiam opinion, vacated the state court's judgment finding as a matter of law that the agent did not have reasonable suspicion to justify a seizure when the agent "stopped" the defendant. Id. at 441 . Although quoting the declaration in Terry that not all intercourse between policemen and citizens constitute seizures, the Court did not mention the Mendenhall decision and did not decide whether the "stop" constituted a seizure requiring reasonable suspicion. Id. A concurring opinion emphasized that that issue was open for the state court to decide on remand. Id. at 443 (Powell, J., concurring). Taking the hint, the Georgia court found no seizure and upheld the conviction. State v. Reid, 247 Ga. 445, 276 S.E. 2d 617, cert. denied, 454 U.S. 883 (1981).

91469 U.S. 1 (1984).

92 Id. at 3-4.

$93 \mathrm{Id}$. at 4.

94 Id. 
bag, which was searched. Cocaine was found and all three individuals were arrested.

Addressing the legality of the officer's actions, the Court first cited Mendenhall and Royer to support the conclusion that "the initial contact between the officers and respondent, where they simply asked if he would step aside and talk with them, was clearly the sort of consensual encounter that implicates no Fourth Amendment interest."95 The Court reached this conclusion with no analysis of the factors deemed significant in Mendenhall and Royer. Particularly in the face of an attempt to flee and a vulgar exclamation by Rodriguez, one wonders what tone of voice the officer used in asking if he and the suspect "might talk." However, the Court went on immediately to state that

Assuming, without deciding, that after respondent agreed to talk with the police, moved over to where his cohorts and the other detective were standing, and ultimately granted permission to search his baggage, there was a 'seizure' for purposes of the Fourth Amendment, we hold that any such seizure was justified by "articulable suspicion."96 But it is not apparent why, if the initial contact was "clearly" not a seizure, the conversation that followed could possibly constitute a seizure. Perhaps it was because the officer was still holding the identification and tickets when Rodriguez gave him consent to the search.

In any event, Rodriguez does not provide significant clarification of the Mendenhall-Royer test. In two sentences, the Court found an initial contact "clearly" was not a seizure, but the conversation which immediately followed was assumed to be a seizure. If it is possible for the Court to provide guidance to lower courts attempting to reach consistent results under Mendenhall-Royer, Rodriguez certainly does not provide it.

The only other post-Mendenhall-Royer Supreme Court decision dealing directly with the issue of when a seizure occurs similarly does not offer much guidance. I.N.S. v. Delgado ${ }^{97}$ involved a challenge to immigration officers' practice of conducting "surveys" of factories in search of illegal aliens. During the surveys, several agents were positioned near the exits while other agents dispersed through the factory to question various employees. The agents displayed badges, carried walkie-talkies, and were armed but never drew their weapons. During the survey, employees continued working and were free to move within the factory. Agents approached

95 Id. at 5-6.

$96 \mathrm{Id}$. at 6.

97466 U.S. 210 (1984). 
employees, asked them between one and three questions relating to citizenship, and in some cases requested immigration papers. In a civil suit challenging the constitutionality of this practice, the Ninth Circuit applied Mendenhall to conclude that during the surveys, which lasted from one to two hours, the entire workforce had been seized because the stationing of agents at the exits meant that "a reasonable worker "would have believed he was not free to leave." "98

The Supreme Court reversed. Addressing the seizure issue, the Court first reiterated what had been said in Terry that "not all personal intercourse between policemen and citizens involves 'seizures' of persons" and reaffirmed that the proper test was whether "a reasonable person would have believed that he was not free to leave."99 Pointing to Royer as "plainly impl[ying] that interrogation relating to one's identity or a request for identification by the police does not, by itself, constitute a Fourth Amendment seizure,"100 the Court found no seizure had occurred when the surveys were conducted. To Justice Rehnquist, the stationing of agents at the exits should not have resulted in any reasonable apprehension that individuals attempting to leave would be seized or detained in any meaningful way. ${ }^{101}$ It was obvious to Justice Rehnquist that the "purpose of the agents' presence at the factory doors was to insure that all persons in the factories were questioned."102 In Justice Rehnquist's view, this did not give the workers reason to believe that they would be detained if they gave truthful answers to questions put to them or simply refused to answer. Moreover, the individual questioning of employees did not constitute a seizure because there could not be a reasonable fear that the employees were not free to continue working or move about the factory. This was despite the fact that indi-

\footnotetext{
98 Id. at 214.

99 Id. at 215.

$100 I d$. at 216.
}

$101 \mathrm{Id}$. at 219. It is not clear why Justice Rehnquist felt that the workers had to fear seizure or detention in a "meaningful" way. Previous cases had made clear that a detention, no matter how brief, constitutes a seizure for fourth amendment purposes. See Reid v. Georgia, 448 U.S. at 440; Florida v. Royer, 460 U.S. at 498 (citing United States v. Mendenhall, 446 U.S. 544, 556 (1980)); Terry v. Ohio, 392 U.S. at 19. Thus, requiring that the detention be "meaningful" beyond a momentary stop would signal a significant change in the definition of seizure. The focus in previous cases, including Mendenhall and Royer, was whether a detention-no matter how brief-resulted from a show of authority or physical force by police, not whether a detention resulting from such action was meaningful in any other sense. It is possible that Justice Rehnquist included the modifier "meaningful" to distinguish it from the momentary pause the worker might have to make to simply listen to the agent's request to answer some questions.

102466 U.S. at 218. 
viduals attempting to flee or evade the agents eventually were detained. 103

Concurring in the result, Justice Powell again characterized the seizure issue as a "close one" because it turned on a "difficult characterization of fact and law: whether a reasonable person in respondent's position would have believed he was free to refuse to answer the questions put to him by INS officers and leave the factory."104 In Justice Powell's view, the issue did not have to be decided because any seizure was of such a character that it was justified as part of the government's special interest in controlling illegal immigration. As one commentator has stated:

Taken at face value, the Court's discussion in Delgado presents a confusing and uncertain application of the objective standard to which a majority of the Justices seem committed. The discussion suggests that a reasonable person would consider himself able in effect to ignore the questions of an officer stationed at the door and would feel free to leave the location. Insofar as this reflects the standard of objective reasonableness adopted by the Supreme Court, the Court seems to have lost contact with reality. If nonarrest detention law is developed on the basis of the Delgado approach, it will leave totally unregulated a large number of situations in which law enforcement activity actually and significantly intrudes upon the liberty interests of citizens. ${ }^{105}$

\section{B. LOWER COURT DECISIONS}

It seems clear that lower courts have taken Delgado at face value. They are engaged in defining the parameters of an artificial reasonable person that has little contact with reality. As Professor Dix predicts, the result is to leave a large number of police-citizen encounters totally unregulated. Moreover, the line between regulated and unregulated police activity is an uncertain one. Because the reasonable person standard is an artificial one and not truly based on whether a citizen feels free to leave, the cases lack consistency

103 Id. at 220.

104 Id. at 221 (Powell, J., concurring).

105 Dix, supra note 6, at 869. Professor Dix goes on to explain:

Alternatively, Delgado can be read as recognizing that a reasonable person would perceive that he was required to stop and listen to an officer's queries, but not to respond. Such a situation, the opinion further suggests, might not be a "meaningful" interference with liberty and thus might not be subject to fourth amendment scrutiny. If this is an accurate reading, the opinion modifies the reasonable expectation test by requiring that the perceived lack of freedom to leave be "meaningful," and by concluding that a detention for purposes of brief questioning is not a "meaningful" interference with the detainee's liberty. This approach either abandons or distorts the reasonable expectation standard.

Id. 
and predictability. Instead, slight factual variations often determine important fourth amendment rights.

Many of the cases applying the Mendenhall-Royer standard involve encounters with air travelers suspected of transporting narcotics. These cases are virtually uniform in holding that a police officer does not seize an individual merely by approaching him or her, asking if he or she would mind answering a few questions, and requesting the individual's identification and airline ticket. ${ }^{106}$ This is probably because it is relatively easy to approach an individual in an airport without restricting that individual's movement and to gain his or her attention politely and ask the initial questions required to characterize the encounter as consensual. ${ }^{107}$ In airports people watch television, sit in bars and snack bars, wait for taxis and luggage, and generally engage in activities that make it easy to approach them without "stopping" them. ${ }^{108}$ Thus, in airport cases the focus of the seizure determination is on police conduct following the initial "approach." 109

106 United States v. Mancini, 802 F.2d 1326 (11th Cir. 1986); United States v. Lehmann, 798 F.2d 692 (4th Cir. 1986); United States v. Palen, 793 F.2d 853 (7th Cir. 1986); United States v. Hanson, 801 F.2d 757 (5th Cir. 1986); United States v. Borys, 766 F.2d 304 (7th Cir. 1985); United States v. Berryman, 717 F.2d 650 (1st Cir. 1983)(en banc); United States v. Pirelli, 650 F. Supp. I 254 (D. Mass. 1986); Wilson v. Superior Court, 34 Cal. 3d 777, 195 Cal. Rptr. 671, 670 P.2d 325 (1983); Jacobson v. State, 476 So. 2d 1282 (Fla. 1985); Goodman v. State, 180 Ga. App. 347, 349 S.E.2d 216 (1986). But see United States v. Woods, 720 F.2d 1022 (9th Cir. 1983)(asking for and taking airline ticket was clear objective indication that suspect was being detained).

107 United States v. Berry, 670 F.2d 583, 595 (5th Cir. Unit B 1982)(“In an airport stop . . . it is possible for [an officer] not to interfere with an individual's progress in any way and to ascertain whether that individual is willing to cooperate ....").

108 United States v. Sokolow, 808 F.2d 1366 (9th Cir. 1987)(agents approach suspect at taxi stand); United States v. Palen, 793 F.2d 853 ( 7 th Cir. 1986)(agents sit next to suspect watching television in concourse); United States v. Mancini, 802 F.2d 1326 (11th Cir. 1986)(agents approach suspect sitting in airport bar); Goodman v. State, $180 \mathrm{Ga}$. App. 347, 349 S.E.2d 216 (1986)(agent sits next to suspect in airport concourse).

109 Street encounters are not so easily accomplished. The officer may be in a squad car while the suspect is walking, riding a bicycle, or also in a car. The officer may not be able to easily "cross paths" with the citizen in order to get her attention politely and to request cooperation without at least momentarily stopping the individual. Courts have struggled with what actions a police officer may take to gain the individual's attention and accomplish the "approach" without implicating the fourth amendment. For example, one court has found that the fourth amendment is not implicated when an officer calls to a citizen, "Police. Wait a second. We want to talk to you," Richardson v. United States, 520 A.2d 692, 697 (D.C. 1987). but is implicated when the officer calls "Come here, police officers." Johnson v. United States, 468 A.2d 1325, 1327 (D.C. 1983). The court cited favorably a pre-Mendenhall case finding no seizure when an officer approached an individual, touched his arm and said, "Hold it, sir, could I speak with you for a second." United States v. Burrell, 286 A.2d 845, 846 (D.C. 1972). If officers "block" an individual's path in order to request cooperation, courts are likely to find a seizure has occurred from the outset of the encounter. See United States v. Verrusio, 
The facts of the airport narcotics cases are remarkably similar. In each case, federal agents develop "suspicion" of a passenger arriving on flights from "source cities." The agents follow the individual for a short time and, before the suspect leaves the airport or when he or she is just outside the airport, approach the suspect, identify themselves, and ask if the suspect will agree to talk to the

742 F.2d 1077 (7th Cir. 1984)(seizure where officer "intercepted" defendant and placed hand on shoulder); State v. Davis, 517 A.2d 859 (N.J. 1986)(officer stopped defendant on bicycle by blocking his path with patrol car). But see Cox v. State, 489 So. 2d 612 (Ala. 1985)(no seizure of defendant sitting in squad car despite directions by sheriff to deputy to "watch him"); Purce v. United States, 482 A.2d 772 (D.C. 1984)(no seizure although defendant testified officer's patrol car blocked his ability to leave in his own car).

Courts similarly have found it difficult to delineate appropriate conduct for police officers approaching individuals in parked cars. Thus, when a police officer parked his car behind and to the left of a car parked in a parking lot and activated his lights prior to approaching the car, a seizure occurred in People v. Bailey, $176 \mathrm{Cal}$. App. 3d 402, 222 Cal. Rptr. 235 (1985), as it did when an officer approached a car parked in an airport parking lot, requested the driver's identification, and asked a question while retaining the license in United States v. Thompson, 33 Crim. L. Rep. (BNA) 2479 (1 1 th Cir. August 22, 1983) (officer testified that he approached defendant to warn him that he faced a large parking lot charge when he exited). However, when an officer parked his squad car behind a car parked in a lot with the driver apparently sleeping or unconscious, tapped on the window with a flashlight, and asked for an explanation of the individual's presence and for identification, a seizure did not occur. Purce v. United States, 482 A.2d 772 (D.C. 1984). Similarly, when an officer followed a car and parked behind it when it stopped to pick up a passenger, approached the car, and requested identification, the encounter was described as "an innocuous police-citizen encounter not implicating the fourth amendment." State v. Harlan, 301 N.W.2d 717, 720 (Iowa 1981).

Obviously, it is difficult for a police officer to be guided by these cases; all four were very similar factually but the results differ. Certainly it seems an officer seeking to avoid a seizure should not activate the lights of the squad car. Presumably this is a "show of authority" indicating the citizen is not free to leave. See People v. Bailey, 176 Cal. App. 3d 235, 222 Cal. Rptr. 235 (1985); State v. Harlan, 301 N.W.2d at 720 (no seizure when officer did not turn on red or yellow flashers); State v. Crespo Aranguren, 42 Wash. App. 452, 711 P.2d 1096 (1985)(important to finding of no seizure that officer did not use flashing lights and siren). If the basis for finding a seizure is that activating lights constitutes a show of authority, is it any less a show of authority to park behind a car and approach it without activating the lights? Certainly a citizen is unlikely to perceive that she is free to drive away in the latter case. Even if the officer does not activate the lights, the cases are unclear as to what further steps the officer may take. Compare United States v. Thompson, 33 Crim. L. Rep. (BNA) 2479 (1 lth Cir. August 22, 1983)(holding license produced on request and asking question constitutes seizure) with Purce v. United States, 482 A.2d 772 (D.C. 1984)(asking for explanation of presence and identification not a seizure). See also People v. Hardy, 42 Ill. App. 3d 108, 491 N.E.2d 493 (1986)(apparently treating initial "stop and questioning" of suspect sitting in parked truck as a seizure beyond scope of Terry stop when officer retained license and asked suspect if he "would mind" accompanying officer to station).

Moreover, even an "innocuous" purpose for the approach will not guarantee a nonseizure determination. One court has found officers approaching a car for reasons other than criminal investigation to have effected a seizure of the occupants of the car. United States v. Thompson, 33 Crim. L. Rep. (BNA) 2479 (11th Cir. August 22, 1983)(officer approached vehicle to warn driver to expect large parking lot charge). 
agents. If, as almost invariably happens, the suspect agrees, the agents request the suspect's identification and airline ticket. The agents generally return the ticket and identification ${ }^{110}$ and request either that the suspect accompany them to an office for further questioning or that the suspect consent to a search of his or her luggage. If the individual consents and drugs are found, the suspect is arrested.

Given the almost uniform facts of these cases, one would expect uniform treatment by the courts. However, even when the final results are the same and the search is found lawful, the ultimate outcome often results from different analyses. Some courts find no seizure occurred and deem the entire transaction consensual and lawful.111 A significant number of courts, however, find the encounter constitutes a seizure at some point. ${ }^{112}$ Often these courts uphold the search nevertheless because the seizure is justified by the required level of suspicion. ${ }^{113}$ In still other cases, courts find sufficient justification for the seizure lacking and suppress the evidence. ${ }^{114}$

Almost all courts accept the proposition that the agents in these cases, by merely approaching the individual, requesting to speak with them, and asking for identification, have not "seized" the individual. Although virtually all courts apply the Mendenhall-Royer test, judicial response to the agents' conduct beyond that point is less

110 This is true at least since Royer in which the Court emphasized the agents' retention of the ticket as crucial to its finding of a seizure. See United States v. Robinson, 690 F.2d 869 (11th Cir. 1982)(agent Markonni testified that returning ticket was part of his "property procedure" for airport encounters).

111 United States v. Mendenhall, 446 U.S. 544 (1980); United States v. Berryman, 717 F.2d 650 (1st Cir. 1983)(en banc); United States v. Regan, 687 F.2d 531 (1st Cir. 1982); United States v. Moore, 675 F.2d 802 (6th Cir. 1982); Pastor v. State, 498 So. 2d 962 (Fla. Dist. Ct. App. 1986)(train station case); Goodman v. State, I80 Ga. App. 347, 349 S.E.2d 216 (1986); State v. Jones, 495 So. 2d 334 (La. Ct. App. 1986).

112 See infra cases cited in notes 116-21.

113 United States v. Lehmann, 798 F.2d 692 (4th Cir. 1986); United States v. Hanson, 801 F.2d 757 (5th Cir. 1986); United States v. Palen, 793 F.2d 853 (7th Cir. 1986); United States v. Borys, 766 F.2d 304 (7th Cir. 1985); United States v. Cordell, 723 F.2d I 283 (7th Cir. 1983); United States v. Wallraff, 705 F.2d 980 (8th Cir. 1983)(assuming seizure, reasonable suspicion present); United States v. Black, 675 F.2d 129 (7th Cir. 1982); United States v. Elsoffer, 671 F.2d 1294 (11 th Cir. 1982); United States v. Davis, 638 F. Supp. 472 (D. Mass. 1986); Stabenow v. State,. 495 N.E.2d 197 (Ind. Ct. App. 1986).

114 United States v. Glass, 741 F.2d 83 (5th Cir. 1984); United States v. Saperstein, 723 F.2d 1221 (6th Cir. 1983); United States v. Regan, 687 F.2d 531 (1st Cir. 1982)(reasonable suspicion justifies detention, but detention exceeds scope of Terry; evidence suppressed); United States v. Robinson, 690 F.2d 869 (1lth Cir. 1982); United States v. Pirelli, 650 F. Supp. 1254 (D. Mass. 1986); United States v. Gallego-Zapata, 630 F. Supp. 665 (D. Mass. 1986); Wilson v. Superior Court, 34 Cal. 3d 777, 195 Cal. Rptr. 671, 670 P.2d 325 (1983); Daniels v. State, 718 S.W.2d 702 (Tex. Crim. App. 1986). 
consistent. Courts have adopted "watershed points,"115 at which the encounter becomes a seizure, that vary from retaining the individual's ticket and identification, ${ }^{116}$ informing the individual of the officer's suspicions, ${ }^{117}$ directing a question to the individual designed to confirm or dispel suspicion, ${ }^{118}$ requesting the individual to accompany officers to another location, ${ }^{119}$ requesting permission to search, ${ }^{120}$ and threatening to seek a warrant to search. ${ }^{121}$ Courts deem these "points" crucial because, in their view, at this point the character of the encounter changes to such a degree that a reasonable person would no longer feel free to walk away.

Beyond the concern that different courts are using different "watershed points," there also exists a concern that these watershed points are merely technical constructs bearing little relation to

115 See United States v. Waskal, 709 F.2d 653, 661 n.14 (11th Cir. 1983)(noting that several courts find retention of ticket and identification to be "watershed point" in seizure determination); United States v. Black, 675 F.2d 129 (7th Cir. 1982)(same); United States v. Viegas, 639 F.2d 42, 44 n.3 (1st Cir. 1981).

116 United States v. Thompson, 33 Crim. L. Rep. (BNA) 2479 (11th Cir. August 22, 1983)(seizure when officer held license while making additional requests); United States v. Robinson, 690 F.2d 869 (11th Cir. 1982); United States v. Elsoffer, 671 F.2d 1294 (11th Cir. 1982).

117 United States v. Hanson, 801 F.2d 757 (5th Cir. 1986)(officer also still retaining license); United States v. Palen, 793 F.2d 853 (7th Cir. 1986)(no seizure until officer told defendant he was suspect and requested consent to search); United States v. Cordell, 723 F.2d 1283 (7th Cir. 1983)(handing I.D. and ticket to another officer and informing defendant of narcotics investigation transformed consensual encounter into detention); Wilson v. Superior Court, 34 Cal. 3d 777, 670 P.2d 325, 195 Cal. Rptr. 671 (1983)(officer told suspect he had information that the suspect was carrying a lot of drugs). See also United States v. Mancini, 802 F.2d 1326 (11th Cir. 1986)(no seizure although officers identified themselves as narcotics officers, but neither accused the defendant nor stated that they suspected him of carrying drugs).

118 United States v. Gallego-Zapata, 630 F. Supp. 665 (D. Mass. 1986)(seizure occurred when officers, after identifying themselves, asked defendant if they could talk and asked from where he was arriving).

119 United States v. Lehmann, 798 F.2d 692 (4th Cir. 1986)(no seizure until agents asked defendant in airport parking lot to accompany them to FAA office); United States v. Tolbert, 692 F.2d 1041 (6th Cir. 1982)(seizure based on request for identification and immediate request to accompany to another location).

120 United States v. Gonzalez, 43 Crim. L. Rptr. (BNA) 2095 (5th Cir. April 1, 1988)(encounter rose to seizure when federal agent tells suspect he is working narcotics and requests permission to look in bag); United States v. Borys, 766 F.2d 304 (7th Cir. 1985)(seizure when police told the individual he was a suspect and requested permission to search); but see Jacobson v. State, 476 So. 2d 1282 (Fla. 1985)(no seizure when officers approached airport travelers, displayed badges, asked to talk, identified themselves as narcotics officers, and requested permission to search); Daniels v. State, 718 S.W.2d 702 (Tex. Crim. App. 1986)(no seizure when officers approached suspect, but seizure occurred when they asked him for identification, identified themselves as police officers, and requested permission to search).

121 United States v. Pirelli, 650 F. Supp. 1254 (D. Mass. 1986)(consensual encounter became seizure when officers asked suspect for consent to search bag and told him they would seek search warrant if consent denied). 
whether the character of the encounter has in fact changed in any significant way so that the citizen feels differently about his or her options to walk away. If courts are attempting to make a realistic appraisal of whether the citizen reasonably feels free to walk away, the encounter should be deemed a seizure at an earlier point. ${ }^{122}$ If that is not their purpose, it must be frustrating to police officers who perceive little difference in their conduct on either side of the "watershed point." Whatever the courts' reasons, the end result is varied treatment of nearly identical situations.

Most courts treat the encounter as a seizure if the agent retains the ticket and identification for even a short period of time beyond that necessary to ascertain the information contained in them. ${ }^{123}$ This apparently is a response to the fact that the primary distinction between Mendenhall, in which Justice Stewart found no seizure, and Royer, in which the Court found a "de facto" arrest, was the officer's retention of Royer's ticket and identification. Lower courts have not failed to notice this point and, understandably, have elevated the factor to crucial importance. Courts are not as certain, however, as to what conduct will constitute a seizure if the ticket is returned.

Several courts have found seizures when police officers inform the individual that the police suspect them of carrying narcotics and request consent to search the suspect's luggage. ${ }^{124}$ These courts seem unwilling to extend the fiction that a reasonable person feels free to leave when approached by a police officer beyond the point where what was already implicit is made explicit-that the individual is suspected of criminal activity. This is a logical extension of the notion that the "nonseizure" category of police-citizen encounters is made up of "innocuous" police-citizen exchanges. It recognizes the reality that encounters in which the officer suspects the individual of criminal activity and is seeking incriminating information are entirely different from encounters "wholly unrelated to the crime fighting function" referred to in Terry. Although these courts are willing to accept the characterization of these encounters as "innocuous" nonseizures when the officer is. polite and does not overtly

122 See United States v. Cordell, 723 F.2d 1283, 1286 (7th Cir. 1983)(Swygert, J., concurring)("as a factual psychological matter people who are stopped for questioning of this kind . . generally do not feel free to leave."); United States v. Black, 675 F.2d 129 (7th Cir. 1982)(Swygert, J., dissenting)(reasonable person does not feel free to leave when first approached); United States v. Barnes, 496 A.2d 1040 (D.C. 1985)(noting that it would be hard to imagine that anyone would feel free to walk away when approached by officer); State v. Valentin, 105 N.J. 14, 519 A.2d 322 (N.J. 1987)(few individuals believe they can refuse to respond to questions by police officers).

123 See cases cited supra note 116.

124 See cases cited supra notes 117 and 120. 
indicate suspicion, they refuse to stretch that characterization to include encounters where the officer makes known his or her suspicions. Although admirable in the protection they provide to citizens by finding a seizure early in the encounter, in reality it is questionable whether the character of these encounters has changed so significantly at this point that it should suddenly be scrutinized under the fourth amendment. ${ }^{125}$ For instance, in United States $v$. Borys, ${ }^{126}$ the defendant was approached and questioned "sporadically" for fortyfive minutes as he moved through the concourse. ${ }^{127}$ Moreover, he was overtly followed between the instances of questioning. The court, although admitting that the suspect may not have felt free to leave, found no seizure because a reasonable person would have felt free to leave. ${ }^{128}$ However, the court did find a seizure when the agents explained to defendant that he was a suspect and requested permission to search his bag. ${ }^{129}$ Surely it was obvious to the defendant-and any reasonable person-that the police suspected him of criminal activity long before this. The court's test is unrealistic if the question is when did the suspect realize this was not an "innocuous" encounter. However, at least the court refused to continue to wear blinders when the police made it explicit that the encounter was for criminal investigation of the defendant. Other courts are unwilling to find a seizure even when this is true. ${ }^{130}$

In truth, courts refusing to find a seizure at the point when po-

125 Police have responded by going to great lengths to avoid expressing their suspicions of the citizen whom they "encounter." See United States v. Berryman, 717 F.2d 651,653 (1st Cir. 1983) (when defendant asked what the problem was, officer responded "drug traffic between Ft. Lauderdale and Boston is high."); Pastor v. State, 498 So. 2d 962, 963 (Fla. Dist. Ct. App. 1986)(officers approached defendant in train station and asked for help "combatting the narcotics problem in South Florida"); State v. Hoffpauir, 44 Wash. App. 195, 197, 722 P.2d 113, 114 (1986)(officer asked defendant to accompany him to discuss "a problem downtown").

126766 F.2d 304 (7th Cir. 1985).

127 Id. at 311.

$128 I d$.

129 Id. However, by this time, the court found that reasonable suspicion justifying the stop existed. The court noted that Borys arrived from a source city, traveled first class but carried two bulky garment bags into and off of the plane, had purchased his tickets with cash, was dressed casually, had no identification, was walking extremely fast, was nervous when questioned, and gave a deceptive answer about the length of his stay in Florida. Id.

130 See United States v. Mancini, 802 F.2d 1326 (11th Cir. 1986)(no seizure when officers identified themselves, explained their purpose of investigating narcotics smuggling, and requested permission to search defendant's bags); Jacobson v. State, 476 So. 2d 1282 (Fla. 1985)(no seizure when officers identified themselves as narcotic agents and requested permission to search bags); State v. Johnson, 317 N.C. 343, 350, 346 S.E.2d 596, 600 (1986)(no seizure even when officer told defendant that "I just wanted to meet a cold-blooded killer."). 
lice inform the individual of their suspicions seem more consistent with Justice Stewart's opinion in Mendenhall. In Mendenhall, the fact that the agents' suspicions were revealed to the defendant and permission requested to search did not move Justice Stewart to find a seizure. ${ }^{131}$ The apparently inconsistent results seem to result from a different focus by the lower courts. Justice Stewart's concern in Mendenhall was whether the police were impolite or overbearing such that a message was conveyed that the individual was not free to leave. ${ }^{132}$ Other courts seem more (or at least also) concerned that the encounter retain a character of a casual, innocent encounter. ${ }^{133}$ Such a focus can lead to seizure determination very early in the encounter. In United States v. Gallego-Zapata, ${ }^{134}$ the government conceded that a seizure occurred when DEA agents identified themselves, requested to talk to the defendants, and asked from where they were arriving. The court agreed stating that "[a]t that point a reasonable person would not have felt free to walk away. Clearly the agents' questions were in the manner of an investigation-an attempt to verify or dispel their suspicions. This went well beyond a casual encounter with a law enforcement officer in a public place."'135

Similarly, in Daniels $v$. State, ${ }^{136}$ the court found no seizure on the initial approach by the agents. However, when the officer asked for identification, informed the suspect that they were narcotics officers, and requested consent to search, a seizure occurred. ${ }^{137}$ The court pointed out that "Justice Brennan would also agree: It is simply wrong to suggest a traveler feels free to walk away when approached by individuals who have identified themselves as police officers and asked for, and received, his airline ticket and driver's license."138

Other courts similarly seem to accept the Mendenhall-Royer test but apply it more strictly than Mendenhall suggests it should be. They have found as little as a request for identification and a request for the individual to accompany the agents to another office to be a seizure. ${ }^{139}$

131446 U.S. at 558.

132 See Williamson, supra note 12, at 801 (recognizing that under Mendenhall social amenities seem to govern seizure determination).

133 See supra discussion accompanying notes 124-30.

134630 F. Supp. 665 (D. Mass. 1985).

$135 \mathrm{Id}$. at 671 .

136718 S.W.2d 702 (Tex. Crim. App. 1986).

137 Id. at 706.

138 Id. at 706 n.2.

139 United States v. Lehmann, 798 F.2d 692 (4th Cir. 1986); United States v. Saperstein, 723 F.2d 1221, 1225 (6th Cir. 1983)(stating that Mendenhall has "clearly been limited to its facts"); United States v. Tolbert, 692 F.2d 1041 (6th Cir. 1982). See also Dix, 
Despite this apparent reluctance to apply Mendenhall-Royer with its full force, there has been little indication that courts may be willing to reject the test itself. Perhaps this is because the courts feel comfortable with the results of applying the "modified" MendenhallRoyer test. They may also be uncertain about the feasibility of other tests. Of course, lower federal courts are not free to reject the Mendenhall-Royer test. However, even commentators have been surprisingly content with the test. ${ }^{140}$ As discussed below, this is in part due to a failure to fairly analyze possible alternatives and a belief that Mendenhall-Royer can be modified to provide appropriate results.

\section{Alternatives to the Mendenhall-Royer Test}

Most commentators recognize that the Mendenhall-Royer test as applied does not distinguish accurately between cases in which an average citizen would and would not feel free to end an encounter with a police officer. It is not accurate because in virtually every police-citizen encounter the average citizen does not feel free to walk away. ${ }^{141}$ Thus, if the Mendenhall-Royer test was applied consistent with reality, all police-citizen encounters would be seizures. ${ }^{142}$ The Mendenhall-Royer test instead classifies some police-citizen encounters as nonseizures based on whether a reasonable person

supra note 6, at 861 (suggesting a stricter application of Mendenhall as a possibility under state law).

140 See Dix, supra note 6, at 867 ("Mendenhall-Royer standard might well be the only appropriate and feasible one"); LaFave, "Fourth Amendment Vagaries," supra note 12, at 1 184-86; Note, "Reexamining Fourth Amendment Seizures: A New Starting Point," 9 HofSTRA L. REV., 211, 229-31 (1980). Even commentators critical of the test seem unwilling to embrace an alternative test that simply focuses on the purpose of the officer in initiating the encounter. See Greenberg, supra note 17, at 73-76 (suggesting per se rule limited to stops based solely on drug courier profile); Williamson, supra note 12 at 788 , 801-02 (suggesting investigatory nature of encounter important, yet not calling for per se rule); Note, "Reformulating Seizures" supra note 17, at 1502-03 (suggesting multifactor test).

141 See Becton, supra note 18, at 467-69; Dix, supra note 6, at 869-70; LaFave, "Seizure Typology: Classifying Detentions of the Person to Resolve Warrant, Grounds, and Search Issues," 17 U. Mrch. J.L. REF. 417, 423-24 (1984) [hereinafter LaFave, "Seizure Typology"]; Williamson, supra note 13, at 801; Note, Calif. L. Rev., supra note 17, at 1502. Courts also recognize this deficiency in the Mendenhall-Royer test. See United States v. Cordell, 723 F.2d 1283 (7th Cir. 1983)(Swygert, J., concurring)(as factual psychological matter people stopped for questions of this kind do not feel free to leave); People v. Spicer, 157 Cal. App. 3d 213, 203 Cal. Rptr. 599 (1985)(greatest legal fiction of the 20th Century may be that people feel free to walk away during police-citizen encounters); United States v. Barnes, 496 A.2d 1040 (D.C. 1985)(hard to imagine anyone feeling free to walk away); State v. Shy, 373 So. 2d 145 (La. 1979)(Dennis, J., dissenting)(to suppose that individual feels free to leave during encounter with police is "fanciful").

142 See LaFave, "Seizure Typology," supra note 141, at 424. 
would have felt free to walk away, ignoring the subjective impressions of the citizen.

The Mendenhall-Royer test also ignores the subjective intent of the officer involved even when that intent is to detain the individual. Justice Stewart made clear in his opinion in Mendenhall that the officer's subjective intention to detain the suspect is irrelevant, unless it is conveyed to the suspect. ${ }^{143}$ Although it is understandable why a suspect's subjective belief cannot decide the issue of seizure, ${ }^{144}$ it is not apparent why the officer's subjective intention should be dismissed as irrelevant. The result in many cases is a characterization of police-citizen encounters that is pure fiction. The citizen does not feel free to leave, ${ }^{145}$ nor will the officer permit it, yet the encounter is a "nonseizure" under the Mendenhall-Royer test. Such a characterization has been described as perhaps "the greatest legal fiction of the late 20th century." 146 Nevertheless, courts persist in having important fourth amendment rights of citizens turn on such a fiction. ${ }^{147}$

An obvious way to avoid this fiction is to consider the subjective intent of the police officer. This would remove at least the "total fiction" cases-those where the citizen does not feel free to leave and, in fact, is not free to leave because the officer would detain her-from the nonseizure category. Because the actual intent of the officer was to detain the individual, a seizure would be found. Of course, under this test, even cases where the individual did feel free to leave, but the officer's intent was to detain, would be seizures.

143 Mendenhall, 446 U.S. 544, 554 n.6 (1980).

144 See LaFave, "Seizure Typology," supra note 141, at 423.

145 This is due either to the inherently compelling nature of the officer's authority or to another subtle reason such as tone of voice or hand on gun. Of course, it is possible that if the overt (but subtle) factors are revealed to the court, a seizure could be found under Mendenhall-Royer.

146 People v. Spicer, 157 Cal. App. 3d 213, 203 Cal. Rptr. 599, 602 (1985). The Court was referring to Justice Dennis' characterization of the test in State v. Shy, 373 So. 2d 145, 149 (La. 1979)(Dennis, J., dissenting):

Once the confrontation was forced by the officers, it is fanciful to suppose that the defendant was free to walk away. The officers admitted in their testimony that if the defendant had attempted to leave he would have been stopped by force. If both officers and the defendant knew that the defendant would be physically restrained if he had tried to walk away, it is legalistic, but not realistic, to pretend that an ordinary citizen would be aware of or believe in, much less rely upon, the majority's shibboleth, viz., "the mere fact that the police approach a citizen and address him does not compel that citizen to respond to the inquiries or comply with their request; legally, nothing prevents his choosing not to answer and walking away."

147 See United States v. Mendenhall, 446 U.S. 544 (1980); State v. Shy, 373 So. 2d 145 (La. 1979); State v. Ferola, 518 A.2d 1344 (R.I. 1986). But see Wells v. State, 716 S.W.2d 715 (Tex. Ct. App. 1986); W. LaFave, Search and Seizure, supra note 12, Section 9.2(h) at $407 \mathrm{n} .219$ (citing decisions of a "few courts" finding seizure based on officer's subjective intentions). 
For that reason, some may view the test as overinclusive; that is, if a person does feel free to leave (even mistakenly) there has been no seizure. However, few cases of that sort are likely to occur when the officer intends to detain.

Professor LaFave voices additional objections to the use of the officer's actual intent. He states that considering the officer's intentions is "not a useful approach." $148 \mathrm{He}$ believes it is unrealistic because in most instances the officer will not think ahead to the possibility of the citizen attempting to leave. ${ }^{149}$ Moreover, according to LaFave, an advance decision by the officer as to whether he or she has sufficient suspicion to detain the suspect if the suspect attempts to leave is irrelevant because evasive action by the suspect may increase the level of suspicion and justify the detention. ${ }^{150} \mathrm{Fi}$ nally, Professor LaFave fears that considering the intentions of police officers will simply mean that the cases will "be decided by swearing contests in which officers would regularly maintain their lack of intention to assert power over a suspect save when the circumstances would make such a claim absurd."151

Although in some cases it will be difficult to ascertain whether the officer intended to detain the suspect, it does not necessarily follow that the officer's subjective intentions are irrelevant. Proof that the officer intended to detain is proof that the citizen was, in fact, seized, and should be at least one method of demonstrating a seizure. Although it may be true in most instances that the officers will not consider the possibility that the suspect may attempt to leave, in some cases the officer will admit that he or she would have detained the individual, and in other cases it will be clear that if the officer had been forced to make the decision, he or she would have detained the suspect. In these instances, a seizure should be found.

The officer's subjective intention also is not rendered irrelevant by the fact that a suspect's attempt to leave can significantly change the situation. An encounter is classified as a nonseizure because, at

148 LaFave, "Seizure Typology," supra note 141, at 422. Professor LaFave also rejects a test based on the subjective intentions of the suspect and a test based on consent. Interestingly, Professor LaFave rejects the latter because "[i]t is nothing more than a fiction to say that all of these suspects have assented to the confrontation." W. LAFAvE, Search and Seizure, supra, note 12, at 408. Yet Professor LaFave does not completely eliminate consent as a consideration. He points out that in some cases "it will be clear that the suspect did consent to the encounter, thus obviating any need to inquire further into the seizure issue." Id. A similar approach could be taken with regard to the officer's subjective intentions. See infra notes 151-54 and accompanying text.

149 LaFave, "Seizure Typology," supra note 141, at 422.

$150 \mathrm{Id}$. at 423.

151 Id. 
least theoretically, a citizen should feel free to leave or decline to cooperate without suffering any consequences. It certainly seems useful to inquire as to the officer's intention in such a case; police officers should know how they would react to a legitimate exercise of rights by a citizen. ${ }^{152}$ Moreover, it seems unlikely that an officer would approach a suspect and then allow the suspect, now alerted to the officer's suspicion, simply to walk away.

Finally, there are two responses to the concern that officers would simply testify that their intention was not to detain the individual regardless of what they truly intended that merit discussion. First, it seems poor fourth amendment jurisprudence to let the possibility of perjury by law enforcement personnel dissuade a court from utilizing, even as an alternative, an appropriate test. ${ }^{153} \mathrm{Sec}-$ ond, it is not at all clear that the Mendenhall-Royer test eliminates the possibility of manipulation of results by the testimony of police officers. If a subtle distinction is drawn between permissible and impermissible exploitation of the inherent coercion of a police officer's authority based on factors such as tone of voice, use of force, and length of control over identification, it seems likely that the result will be swearing contests in which officers regularly maintain that their conduct, tone of voice, and statements to the suspect were pleasant and polite, suggesting nothing remotely close to a show of authority, while the suspect's recollection of the transaction will be just the opposite. ${ }^{154}$

152 In Goodman v. State, 180 Ga. App. 347, 349 S.E.2d 216 (1986), when a suspect asked Agent Markonni, perhaps the most experienced agent in airport stops, what would happen if the suspect refused consent, Markonni replied that he "did not want to discuss that" and would like the suspect to make the decision. The court found no seizure occurred under these circumstances. One wonders how a citizen is supposed to know whether or not he or she is free to refuse consent and walk away if the officer is not certain or at least is unwilling to reveal his intentions.

153 See Burkoff, "Bad Faith Searches," 57 N.Y.U. L. REv. 70, 112-13 (1982).

154 Of course, it may be easier-or at least less subject to detection-to lie about one's state of mind as opposed to lying about actions actually taken. However, a significant problem in determining what actually happened during police-citizen encounters exists. See United States v. Sokolow, 808 F.2d 1366 (9th Cir. 1987)(federal agents and defendant do not remember events in same way; court accepts defendant's version); United States v. Palen, 793 F.2d 853 ( 7 th Cir. 1986)(several discrepancies between officers testimony and that of defendant); United States v. Verrusio, 742 F.2d 1077 (7th Cir. 1984)(court disbelieves agent's testimony concerning timing of explaining constitutional rights); United States v. Waskal, 709 F.2d 653 (11th Cir. 1983)(defendant's version of facts differs substantially from officer's; states attorney originally refused to prosecute because persuaded by defendant's account); United States v. Wallraff, 705 F.2d 980 (8th Cir. 1983) (court notes discrepancy between agent's version and defendant's version of the encounter); United States v. Berry, 670 F.2d 583 (5th Cir. Unit B 1982)(noting the difficult factual findings required under Mendenhall-Royer standard and that they are subject to easy distortion or poor recall); United States v. Pirelli, 650 F. Supp. 1254 (D. 
Professor LaFave suggests that rather than abandoning the Mendenhall-Royer test, the standard simply should not be given a literal reading. He proposes:

[W] hat is needed is an interpretation of the Mendenhall-Royer test which is grounded in the proposition that police, without having later to justify their conduct by articulating a certain degree of suspicion, should be allowed "to seek cooperation, even where this may involve inconvenience or embarrassment for the citizen, and even though many citizens will defer to this authority of the police because they believe-in some vague way-that they should."155

Professor LaFave then provides the required interpretation. Under his interpretation, the seizure question turns on whether the officer adds to the inherent pressures that compel individuals to cooperate with police officers "by engaging in conduct significantly beyond that accepted in social intercourse." 156 Under this standard, "[t]he critical factor is whether the [police officer], even if making inquiries a private citizen would not, ${ }^{157}$ has otherwise conducted himself in a manner which would be perceived as a nonoffensive contact if it occurred between two ordinary citizens."158

Although, as Professor LaFave asserts, this approach may be more compatible with the various views expressed in Royer and comes closer to explaining the results in the cases than the reason-

Mass. 1986)(officer admits lying about whether telephone tip was received which formed basis for stop); Wilson v. Superior Court, $34 \mathrm{Cal}$. 3d 777, 670 P.2d 325, 165 Cal. Rptr. 671 (1983)(same); Purce v. United States, 482 A.2d 772 (D.C. 1984)(dispute in testimony concerning whether squad car blocked suspect's ability to leave); Stabenow v. State, 495 N.E.2d 197 (Ind. Ct. App. 1986)(one officer states he told suspect he was free to leave but another officer "disagrees"); People v. Chinchillo, 120 A.D.2d 266, 509 N.Y.S.2d 153 (App. Div. 1986)(noting that witnesses for state and for defense testified in directly contradictory fashion; lower court found both worthy of belief); Daniels v. State, 718 S.W.2d 702, 704 n.1 (Tex. Crim. App. 1986)(noting that defendant testified that officer did not approach and request consent to search, but blocked his path, slammed him against lockers, and started searching).

155 W. LaFave, Search and Seizure, supra note 12, at 411 (quoting Model Code of Pre-Arraignment Procedure 258 (1975)).

156 Id. at 412.

157 This is necessary to Professor LaFave's test if he is to avoid the same pitfall as the Mendenhall-Royer test, that is, literal application resulting in every encounter being found to be a seizure. This is so because one of the first questions asked is for identification, something a private citizen would not ask. Of course, the disadvantage of this qualification to the test is that it reintroduces artificiality and is likely to result in decisions as inconsistent as those under Mendenhall-Royer.

158 Id. Professor LaFave explains that:

Under this approach, an officer has not made a seizure if, for example, he interrogated "in a conversational tone," "did not order the defendant" to do something or "demand that he" do it, did not ask questions that were "overbearing or harassing in nature," and did not "make any threats or draw a weapon."

Id. at 412-13. 
ing typically offered, ${ }^{159}$ it is less clear that it "strikes an appropriate balance in marking the reach of Fourth Amendment protections"160 or is even a workable standard. The approach expands the proposition that "the moral and instinctive pressures [on citizens] to cooperate [with police officers] are in general sound and may be relied on by the police" 161 to include encounters between police and suspects in which the cooperation sought by the police is the incrimination of the citizen herself. The validity and desirability of such an expansion is questionable. ${ }^{162}$

Expanding the proposition that police officers should be permitted to rely on the "moral and instinctive pressures to cooperate" to include situations in which the officers are seeking self-incriminating cooperation fails to give adequate weight to the fifth amendment implications of police-suspect encounters. The police have no authority to gather evidence through a frisk or search, because reasonable suspicion does not exist in many of these encounters. Instead, the officers' aim is to have the suspect incriminate herself "voluntarily" by confessing, providing an explanation that heightens the level of suspicion, or consenting to a search. Under present fifth amendment principles, obtaining evidence in this manner does not violate that amendment. The suspect is not in custody for purposes of Miranda, ${ }^{163}$ and the evidence gained through a consent search is not compelled and often is not testimonial. ${ }^{164}$ Nevertheless, when police approach a citizen in a manner that they know will make the citizen feel restrained, they create a situation in which the citizen no doubt feels the need to take some action to quell the suspicion aroused in order to continue on his or her way. Frequently, the suspect will consent to a search or otherwise provide incriminating evidence. ${ }^{165}$ It seems incorrect to say such conduct does not implicate constitutional protections and therefore will not be subject to scrutiny by the courts.

Another possible alternative to the current approach is to focus

159 Id. at 417 .

$160 \mathrm{Id}$.

161 Model Code of Pre-Arraignment Procedure $\$ 110.1$ Comment at 258 (1975).

162 Professor LaFave cites the MODEL CODE as support for this expansion but ignores the CoDE's recognition of the distinction between police-citizen encounters and policesuspect encounters. See infra note 166.

163 Miranda v. Arizona, 384 U.S. 436 (1966). See also Berkemer v. McCarty, 468 U.S. 420 (1984); Dix, supra note 6, at 939-951.

164 Use of physical evidence acquired during a search does not implicate the fifth amendment. Schmerber v. California, 384 U.S. 757 (1966).

$165 S_{e e}$ Greenberg, supra note 17, at 75 (noting that initial non=seizure encounter with citizen only has enforcement utility if agents eventually achieve a more extensive intrusion). 
on the purpose of the encounter. If the officer approaches the individual to investigate that individual's involvement in criminal activity, the encounter would be deemed a seizure from the start. Such a test has gained little support. However, the Model Code of PreArraignment Procedure does recognize the distinction between police-citizen encounters and police-suspect encounters. ${ }^{166}$ It includes special provisions for questioning suspects as opposed to seeking cooperation from citizens and requires warnings to suspects that no legal obligation exists to respond to questioning. ${ }^{167}$ Although courts understandably may be reluctant to require warnings outside the Miranda context, ${ }^{168}$ a seizure test that focuses on the purposes of the police in initiating encounters with citizens can provide some protection to citizens in police-citizen encounters in which the police are seeking incriminating evidence from the citizen. Such a standard has been adopted in California. ${ }^{169}$ This standard provides needed protection in an area not presently scrutinized under the Mendelhall-Royer test, is more workable, and leads to more consistent results than that test.

In In re Tony C. ${ }^{170}$ the California Supreme Court held that fourth amendment rights are implicated whenever an individual is

166 See Model Code of Pre-Arraignment Procedure $\$ 110.1(1)$-(2). Subsection (1) provides that officers "may, subject to the provisions of this Code . . . request any person to furnish information or otherwise cooperate in the investigation or prevention of crime" without informing the individual of their right to refuse to cooperate. Subsection (2), however, requires that if an "officer, acting pursuant to this Section, suspects or has reasonable cause to suspect that a person may have committed a crime, he shall ... take such steps as are reasonable under the circumstances to make clear that no legal obligation exists to respond to the questioning." The commentary to Section 110.1 explains this distinction. The commentary points out that while the explicit authorization to the police to seek cooperation is a recognition that "the moral and instinctive pressures to cooperate are in general sound and may be relied on by the police," restrictions are nevertheless appropriate where "police conduct . . . conflicts with particular rights-such as the privilege against self-incrimination." Thus, subsection (2) places restrictions on an officer's ability to seek cooperation from a suspect. Both Justice Stewart in Mendenhall and Professor LaFave cite the MODEL CODE and Commentary to support applying the "non-seizure" category to instances of officers approaching suspects. This seems misleading in light of the Code's explicit limitation on such conduct in Section $110.1(2)$.

167 Model Code of Pre-Arraignment Procedure § 110.1(2).

168 See Dix, supra note 7, at 928 (discussing applicability of Miranda to brief encounters); Greenberg, supra note 135, at 76 (suggesting warnings as alternative test for seizure determination); Williamson, supra note 12, at 801 (explaining Miranda not applicable but warning of freedom to leave not inconsistent with Miranda and could be justified by need to clarify encounters). Some courts find the absence of warnings crucial in making the seizure determination, and some police officers apparently now provide appropriate warnings as a routine matter. See Pastor v. State, 498 So. $2 d 962$ (Fla. Dist. Ct. App. 1986); State v. Hoffpauir, 44 Wash. App. 195, 722 P.2d 113 (1986).

169 See In re Tony C., 21 Cal. 3d 888, 582 P.2d 957, 148 Cal. Rptr. 366 (1978).

170.Id. 
stopped or detained because the officer suspects the individual may be personally involved in some criminal activity, but not when the officer acts for other proper reasons. ${ }^{171}$ Professor LaFave criticizes this test as being "certainly [in] error to the extent that it would remove the protections of the fourth amendment from those who do not happen to be suspected of criminal activity." 172 Even if such a result is intended by the Tony $C$. decision, it is not the necessary result of using such a standard. That the Tony $C$. test is by definition limited to encounters with those suspected of criminal activity does not mean that citizens involved in other types of police encounters are without fourth amendment protection. Rather, it simply means the line may be drawn at a different point in those encounters. When a police officer approaches a citizen and asks questions as part of the officer's "community caretaking function," to seek the citizen's cooperation, or for reasons other than suspicion that the citizen is involved in a crime, the fourth amendment will not be implicated until a seizure occurs as defined by either the MendenhallRoyer standard or some other standard based on what actions are appropriate in such a situation. ${ }^{173}$ However, if the officer suspects the individual approached of involvement in criminal activity, the fourth amendment will be implicated immediately. Such a two-test scenario is both practical and logical. ${ }^{174}$

The two-test scenario is practical in part because the issue of

171 Id. at 893, 582 P.2d at 961, 148 Cal. Rptr. at 370.

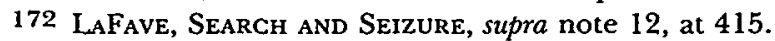

173 For instance, in Florida v. Rawlings, 391 So. 2d 269 (Fla. Dist. Ct. App. 1980), the police received a report of a shooting outside a home and encountered two individuals when they arrived at the scene. Simply approaching those individuals would not be a seizure because the officers have no reason to believe those individuals are involved in the crime. However, the individuals are not without fourth amendment protections. Certainly if the officers detain them by ordering them to remain or drawing their weapons, or if they frisk the individuals, fourth amendment activity has occurred requiring objective justification. Courts may also develop standards under which a seizure occurs at an earlier point, when the officers develop suspicions that the individual is the perpetrator of the crime, or perhaps, only if those suspicions are communicated to the individual. In any event, simply using the purpose of the stop test suggested by Tony $C$. for encounters with suspects does not necessarily require stripping non-suspects of all fourth amendment protection as Professor LaFave suggests. See also People v. Epperson, 187 Cal. App. 3d 115, 232 Cal. Rptr. 16 (1986)(applying Mendenhall-Royer test to encounter with non-suspect); State v. Goetaski, 39 Crim. L. Rep. (BNA) 2165 (N.J. Super, Ct. April 18, 1986)(recognizing that "so-called 'benign' stops" require different analysis); State v. Chisholm, 39 Wash. App. 864, 696 P.2d 41 (1985)(suggesting that stops made for noncriminal, non-investigatory purposes should be analyzed under different standard than stops for criminal investigation purposes).

174 See Williamson, supra note 12 , at 802 ("The perception [of restricted liberty] is much more likely to arise when conduct of police is linked to investigation of specific criminal activity."). See also supra note 173 . 
whether a police-citizen encounter with a nonsuspect constitutes a seizure will not arise frequently. As Professor LaFave points out, if the person stopped is merely a potential witness, it is unlikely that the person "will have the occasion or desire to challenge this action unless something incriminating that person occurs as a consequence of the stop." 175 Of course, there is some danger that the police will attempt to use the "community caretaking function" as a pretext for the stop of a suspect to take advantage of the more relaxed seizure standard for such encounters. ${ }^{176}$ Courts will have to be somewhat vigilant in this area, ${ }^{177}$ and there may be some difficult cases. However, given the simplicity of the inquiry-whether the person was approached because they were suspected of criminal activity or for some other legitimate reason-the issue should be much less difficult than the current determination of whether a seizure has occurred. In most of the difficult seizure cases to date, the purpose for which the officers approached the individuals was apparent: ${ }^{178}$ to investigate the individual's involvement in criminal activity.

The distinction between the two types of cases is also logical. A test based on the purpose of the police in initiating an encounter recognizes the wholly different character of police-suspect encounters, resulting in large part from the self-incrimination implications of those encounters. ${ }^{179}$ Moreover, it provides more consistent results and strikes a more appropriate balance between fourth amendment protections and the need to fight crime. ${ }^{180}$

\section{The "Purpose of the Stop" Test}

The starting point for the present notion of a category of police-citizen encounters not amounting to a seizure is Chief Justice Warren's observation in Terry that "[o]bviously not all personal intercourse between policemen and citizens involves 'seizures' of per-

175 W. LAFAve, SEARch \& SeIzure, supra note 12, at 353.

176 See United States v. Thompson, 33 Crim. L. Rep. (BNA) 2479 (1 1th Cir. August 22,1983 )(officer approached vehicle to warn driver to expect large parking lot charge); United States v. Dunbar, 470 F. Supp. 704 (D. Conn. 1979), aff'd, 610 F.2d 807 (2d Cir. 1979)(officer stopped vehicle because he believed driver was lost); State v. Chisholm, 39 Wash. App. 864, 696 P.2d 41 (1985)(officer testifies that he stopped truck to inform occupant that hat in bed of pick-up might blow out).

177 See Burkoff, "The Pretext Search Doctrine: Now You See It, Now You Don't," 17 U. MICH. J.L. REF. 523 (1984) [hereinafter Burkoff, "Pretext Search Doctrine"]; Burkoff, "Bad Faith Searches," 57 N.Y.U. L. REv. 70 (1982).

178 In virtually all the airport stop cases there was no question but that officers approached the individuals because they suspected them of criminal activity-transporting narcotics.

179 See infra notes 193-202 and accompanying text.

180 See infra notes $219-26$ and accompanying text. 
sons."'181 Chief Justice Warren further observed:

Street encounters between citizens and police officers are incredibly rich in diversity. They range from wholly friendly exchanges of pleasantries or mutually useful information to hostile confrontations of armed men involving arrests, or injuries, or loss of life. . . Encounters are initiated by the police for a wide variety of purposes, some of which are wholly unrelated to a desire to prosecute for crime. ${ }^{182}$

Unfortunately, in creating the Mendenhall-Royer test, the Supreme Court ignored the wide variety of purposes for which encounters are initiated by police. Instead, the Court distinguished the encounters solely on the basis of whether a reasonable person would feel free to end the encounter. Thus, the Court treated identically individuals whom police approach for the purpose of discovering whether that individual is involved in criminal activity and individuals to whom police desire to speak for other, innocuous reasons. ${ }^{183}$ The Court simply ignored the fifth amendment implications of police activity for the former purpose. As a result, police officers are permitted to approach citizens without any objective justification and, by using the inherent coerciveness of their authority, convince them that they are not free to leave and that the best course is to incriminate themselves by confessing or consenting to a search, provided the officers do not act in a fashion that triggers the reasonable person test.

In part, the willingness of the Court to permit officers to take advantage of the inherent coerciveness of their authority in these "nonseizure" scenarios is a manifestation of the increased value the present Court places on confessions, and the increased recognition it gives to the desirability of citizen cooperation with police officers. ${ }^{184}$ The flaw in this elevation of citizen cooperation is the fail-

181 Terry v. Ohio, 392 U.S. at $19 \mathrm{n} .16$. Justice White also observed in his concurrence in Terry that "there is nothing in the Constitution which prevents a policeman from addressing questions to anyone on the streets." Id. at 34. Justice Harlan, in his concurrence, likewise observed that police officers have "the liberty, (again possessed by every citizen) to address questions to other persons, for ordinarily the person addressed has an equal right to ignore his interrogator and walk away." Id. at 32-33.

$182 I d$. at 13.

183 The court in In re Tony $C$. observed:

Such reasons are obviously too many and too varied to recite, but they may be grouped in at least two general categories: (1) the officer may wish to question the person not as a suspect but merely as a witness to a crime, or (2) the officer may be engaged in one of "those innumerable miscellaneous tasks which society calls upon the police to do which have nothing to do with detection of crime" . . such as giving aid to persons in distress, mediating domestic quarrels, assisting the elderly or disabled, furnishing traffic advice or directions, and generally preserving the peace and protecting persons from harm or annoyance.

21 Cal. 3d at 895, 582 P.2d at 961, 148 Cal. Rptr. at 370.

184 In Miranda, although recognizing the obligation of citzens to cooperate with po- 
ure to distinguish between the citizen's duty to cooperate with police in their attempts to serve and protect the community and apprehend other individuals suspected of criminal activity and the citizen's duty to cooperate in implicating themselves in criminal activity. ${ }^{185}$ There is no duty in the latter case. ${ }^{186}$

Historically, courts have differentiated police attempts to solicit cooperation from criminal suspects. Such different treatment is mandated by the fifth amendment and was central to the Miranda decision. Although Miranda limited its specific protection to custodial interrogations of suspects, it does not necessarily follow that all other situations should be categorized as having no fifth amendment implications. While the specific protections of Miranda are not required in other settings, other protections may be appropriate in light of remaining fifth amendment concerns. ${ }^{187}$ Article 110 of the Model Code of Pre-arraignment Procedure distinguishes between "Requests for Cooperation" and "Questioning of Suspects" on that basis, ${ }^{188}$ drawing support from the UNIFORM CODE OF MILITARY JUSTICE and the ENGLISH JUDGES RULES. ${ }^{189}$

Although full recognition of the fifth amendment implications

lice, the Court ruled that, in the absence of warnings, even voluntary confessions by citizens should be excluded if they resulted from custodial interrogation. In large part this was due to the perceived dangers of relying on such evidence. More recently, the Court's view of the value of confessions has changed dramatically. See Moran v. Burbine, 475 U.S. 412 (1986) (admissions of guilt are essential to society's compelling interest in finding, convicting, and punishing those who violate the law); Van Kesell, "The Suspect as a Source of Testimonial Evidence: A Comparison of the English and American Approaches," 38 Hastings L.J. 1, 1-6 (1986). This shift in emphasis clearly has an impact on the Court's treatment of even noncustodial cooperation.

185 It is important that the Court's statement in Miranda that "[i]t is an act of responsible citizenship for individuals to give whatever information they may have to aid in law enforcement," followed immediately the Court's assurances that "[g]eneral on-thescene questioning as to facts surrounding a crime or other general questioning of citizens . . . is not affected by our holding." 384 U.S. at 477 . Moreover, this language has been cited by the Court to support cooperation of third-parties with the police. See Scheckloth v. Bustamonte, 412 U.S. 218, 232 (1973). See also Coolidge v. New Hampshire, 403 U.S. 443,488 (1971)(referring to cooperation of third-party, Court stated that "it is no part of the policy underlying the [f] ourth and [f]ourteenth amendments to discourage citizens from aiding to the utmost of their ability in the apprehension of criminals.").

186 Dix, supra note 6, at 939 (it seems reasonably clear that the federal fifth amendment privileges apply to inquiries by law enforcement officers in the context of questioning non-arrest detainees).

187 See id. at 937-51 (discussing applicability of fifth amendment right against self-incrimination and Miranda in nonarrest detentions); Williamson, supra note 12, at 797-802 (same).

188 Model Code of Pre-Arraignment Procedure, § 110.1 Comment at p. 258.

$189 \mathrm{Id}$. at 260. For a discussion of the history of the ENGLISH JudGes' RuLEs and a comparison of American and English treatment of the questioning of suspects, see generally Van Kessel, supra note 184. 
of these encounters suggests the need for warnings, ${ }^{190}$ this is a step the Supreme Court is certainly unwilling to take, and state courts may be similarly hesitant. Requiring a series of different warnings for different situations may ask too much of law enforcement officials and place added pressure on the exclusionary rule. On the other hand, completely foregoing scrutiny of these encounters-the result in many cases under the Mendenhall-Royer test-swings the pendulum too far in the other direction.

Adoption of a seizure standard that focuses on the purpose for which police initiate the encounter provides an alternative means to accomplish needed judicial scrutiny of these encounters. ${ }^{191}$ Quite simply, whenever a police officer initiates an encounter with a citizen because the officer suspects the citizen may be personally involved in criminal activity, the fourth amendment rights of that citizen are implicated and the officer's actions require objective justificationreasonable suspicion. Conversely, if the officer initiates the encounter for some other purpose, because the citizen is a witness, or as part of "those innumerable miscellaneous tasks which society calls upon the police to do which have nothing to do with the detection of crime,"192 the contact itself will not trigger fourth amendment protections, although additional acts by the officer may. ${ }^{193}$ Such a standard recognizes the important distinction between the different types of police-citizen encounters, more properly balances the competing interests of the individual and the state, and provides a more workable standard.

This distinction seems to be at the heart of the analysis offered by the late Judge Swygert of the Seventh Circuit in a series of seizure cases. In United States $v$. Berryman,$^{194}$ police approached a drug courier suspect at Logan Airport, questioned him, and eventually obtained his consent to search his suitcase and a package inside the suitcase. When the officers found cocaine, they arrested the de-

190 Warnings are required by the Model Code, the ENGlish Judges Rules, and the Military Code of Justice. See also Dix, supra note 6, at 951 (advocating some type of warnings although not identical to Miranda warnings); Greenberg, supra note 17, at 76 (suggesting need for warnings in those encounters); Williamson, supra note 12, at 801 (recognizing Miranda not applicable but warnings not inconsistent with that decision and could be justified by need to clarify encounters).

191 Another method of increasing judicial scrutiny of police-citizen encounters is to increase the number of different "levels" of encounters and make more levels subject to fourth amendment scrutiny. See People v. DeBour, 40 N.Y.2d 210, 352 N.E.2d 562, 386 N.Y.S.2d 375 (1976); LAFave, Search \& Seizure, supra note 12, at 420-22 (discussing DeBour).

192 In re Tony C., 21 Cal. 3d at 895, 582 P.2d at 961,148 Cal. Rptr. at 370.

193 See supra notes $166-68$ and accompanying text.

194717 F.2d 651, rev'd, 717 F.2d 650 (1st Cir. 1983)(en banc). 
fendant. Judge Swygert, writing the majority panel opinion, concluded that a seizure had occurred during the questioning of the defendant. Judge Swygert noted that in his view the seizure determination should not be made in a vacuum, limited to the physical circumstances of the encounter and independent of the reason for the officers' approach, because doing so provided the police with virtually unfettered discretion in making arbitrary and discriminatory stops. ${ }^{195}$

Judge Swygert carefully noted that such an analysis was not inconsistent with the Supreme Court's admonition that "not all personal intercourse between citizens and police officers involves seizures of the persons." 196 He pointed out that asking for directions, questioning potential witnesses, and similar activities by the police will likely invoke no fourth amendment concerns. The reason for this, Judge Swygert reasoned:

is not that "law does not concern itself with trifles;" it is because these situations, unlike inherently confrontational ones, do not pose any risk of arbitrary or abusive exercise of discretion. But whenever an officer identifies himself as a drug enforcement agent and singles out an individual for questioning, the implication of suspicion and the potential for abuse are clear. ${ }^{197}$

Thus, in such situations a seizure has occurred. Finally, Judge Swygert was careful to explain that this does not mean that in such situations the police action may not be justified by an appropriate level of suspicion, or that the level of suspicion must be the same as that necessary for other types of seizures. That would represent a strict categorization of police conduct into a single discreet category, an approach rejected by the Supreme Court in Terry. Instead, the interests involved must be balanced. But when the police have, or at least offer, no individualized suspicion, the government's main interest, in fact, is in avoiding arbitrariness. ${ }^{198}$

Although Berrymian was reversed ${ }^{199}$ and citation can be made to cases rejecting "per se condemnation of voluntary suspect questioning," 200 Judge Swygert's analysis seems to be consistent with those cases that advance the seizure determination to a point early in the police-citizen encounter. Those courts seem unwilling to character-

195 Id. at 658 .

196 Id. at 659.

$197 \mathrm{Id}$.

198 Id.

199 United States v. Berryman, 717 F.2d 650 (1st Cir. 1983)(en banc).

200 See id. at 661 (Breyer, J., dissenting)(later adopted as en banc opinion)(citing United States v. Moya, 704 F.2d 337 (7th Cir. 1983); United States v. Collis, 699 F.2d 832 (6th Cir. 1983)). 
ize the encounter as "innocent" at the point when the confrontational aspects become clear and to treat the encounter the same as any other encounter. They appear to recognize that more than physical circumstances make up the seizure determination, although their "watershed points" are physical circumstances. ${ }^{201}$

As Judge Swygert explains, recognizing the fifth amendment or confrontational implications of police-citizen encounters provides protection against arbitrary stops. Although the Supreme Court has expressed concern over the such stops, ${ }^{202}$ the Mendenhall-Royer standard actually encourages arbitrariness. ${ }^{203}$ Under Mendenhall-Royer, provided that the officer is sufficiently polite and non-threatening, the officer need not provide objective justification for his or her actions in contacting a citizen. ${ }^{204}$ Given the inherent coerciveness of the officer's authority, exploitation of which is deemed sound under Mendenhall-Royer, these stops without objective justification are frequently successful. ${ }^{205}$ One commentator has suggested an additional level of scrutiny beyond Mendenhall-Royer to protect against arbitrary stops. ${ }^{206}$ Requiring objective justification for a larger category of police-citizen encounters is another way to provide protection against the arbitrary exercise of police authority.

A standard focusing on the purpose of the police-citizen encounter also avoids vastly different results in cases with similar facts-a concern of the Terry court itself. ${ }^{207}$ Additionally, it should be easy to determine whether an officer approached a citizen in order to investigate that citizen's involvement in criminal activity, thus providing consistency in the decisions as to which encounters constitute seizures. This is so primarily because if the officer asserts

201 See supra notes 124-30.

202 See Greenberg, supra note 17, at 52 n.20; I.N.S. v. Delgado, 466 U.S. 210 (1984). 203 Reid v. Georgia, 448 U.S. 438 (1980)(no reasonable suspicion justifying encounter; upheld as "non-seizure" by state court on remand); United States v. Moore, 675 F.2d 802 (6th Cir. 1982)( no reasonable suspicion at time of stop, but non-seizure until probable cause developed); State v. Crespo-Aranguren, 42 Wash. App. 452, 711 P.2d 1096 (1985) (although unnecessary to decision in light of finding no seizure, court points out unlikely sufficient justification for stop).

204 See Williamson, supra note 12, at 801 (difficult to understand why social amenities should govern fourth amendment protections).

205 See supra note 203. For a discussion of the prevalence of police use and abuse of the "non-seizure" category of police citizen encounters, see Burkoff, "Non-investigatory Police Encounters," 13 HaRv. C.R.-C.L. L. REv. 681 (1978); Reich, "Police Questioning of Law Abiding Citizens," 75 Yale 1161 (1966).

206 See Murphy, "Encounters of a Brief Kind: On Arbitrariness and Police Demands for Identification," 1986 ARIz. ST. L.J. 207, 226 (1986).

207 Terry v. Ohio, 392 U.S. at 19; Note, "Reformulating Seizures," supra note 17, at 1495-96. Most obviously, such a standard will eliminate the current disparity in treatment between automobile stops and pedestrian stops. 
that investigating the individual for involvement in criminal activity was not the officer's motivation, the officer will be required to provide an alternative explanation. ${ }^{208}$ Although this may raise the issue of pretextual bases for approaching a suspect, such pretexts should not be difficult to identify. Reasons for contact with a citizen that would not trigger fourth amendment protections are very unlike a criminal investigation, and objective evidence of the existence of reasons for a non-investigatory stop should be available. ${ }^{209}$

Of course, courts will still have to make the decision whether reasonable suspicion justifying a particular seizure was present. This determination creates the possibility of divergent results under similar factual settings. However, this is true even under the Mendenhall-Royer standard when a court finds a seizure. ${ }^{210}$ At least a more easily applied seizure test eliminates one pitfall in analyzing the legal effect of police contacts with citizens. Moreover, the existence of reasonable suspicion is easier to determine than whether a reasonable person would feel free to leave because it depends only on the actions of the suspect. The Mendenhall-Royer test requires courts to balance a variety of factors that focus on the behavior of both the suspect and the officer: whether the suspect was walking or sitting; whether the suspect expressed a desire to leave; whether identification was requested and how quickly it was returned; whether the suspect was moved to a different location and how far away it was; the tone of voice used by the officer; and the extent to which any mannerisms of the officer indicated a show of force. ${ }^{211}$

A standard based on the purpose of the contact also provides better guidance to the officer in the field. ${ }^{212}$ The Mendenhall-Royer standard provides incentives to intercede at an early point and not to think carefully about the decision to do so because no objective

208 See In re Tony C., 21 Cal. 3 d at 896 n.3, 582 P.2d at 961 n.3, 148 Cal. Rptr. at 370 n.3.

209 Of course, the issue of police manipulation of facts to create such reasons is a possibility. However, the possibility of police manipulation of facts is present regardless of the test used. It is not, as Professor LaFave suggests, unique to a test based on the subjective intentions of the officer. See supra notes 152-54 and accompanying text.

210 In fact, to the extent courts characterize the encounters as non-seizures and decline to make the reasonable suspicion determination, development of precedent regarding what constitutes reasonable suspicion will be frustrated.

211 See supra Section IIIB. See also Williamson, supra note 12, at 792-802.

212 W. LaFave, Search and Seizure, supra note 12, at 407 ("[A]ny test intended to determine what street encounters are not seizures must be expressed in terms that can be understood and applied by the officer."). The Supreme Court also has recognized this as an important consideration. See Michigan v. Chesternut, 43 Crim. L. Rptr. (BNA) 3077,3079 (U.S. S. Ct. June 13, 1988)(objective test allows officer to determine in advance whether his or her conduct will constitute a seizure). 
justification is required if the officer can avoid conduct that constitutes a seizure. However, this increases the possibility of a misstep by the officer resulting in the loss of evidence. If the officer's mannerisms unknowingly create a show of authority ${ }^{213}$ or if the officer retains the citizen's identification too long, the encounter could be classified as a seizure and, because the officer interceded at an early point, reasonable suspicion to justify the seizure will not be present. Under the proposed standard, because the officer knows the purpose of the contact, he or she will also know objective justification is required and will refrain from acting until such justification is present. ${ }^{214}$ The danger of a misstep by the officer that converts the contact into a seizure is substantial under the Mendenhall-Royer test due to the artificiality of that test. Because the decision as to whether a reasonable person would feel free to leave bears little relationship to whether the average citizen in fact would feel free to leave, knowledge of court precedents rather than common sense must guide the officers.

Finally, a standard based on the purpose of the contact eliminates the fiction now used to determine the fourth amendment rights of citizens. ${ }^{215}$ The result is more consistent treatment of citizens. Under such a standard, all individuals with whom police officers initiate an encounter for the purpose of investigating that individual's involvement in criminal activity will be required to submit to the intrusion because their actions have provided the police with objectively justifiable reasons to so intrude. Individuals will no longer be required to submit simply because police had a "hunch" and the court was willing to let them exploit the inherent coerciveness of their authority.

There are, of course, reasons why a court may be unwilling to adopt such a test. To some extent, it may be reminiscent of the focus test, whereby certain protections were obtained by a suspect when police developed a certain level of suspicion about that suspect. ${ }^{216}$ That test was discarded, in part, because of obvious line

213 Perhaps by force of habit the officer places his or her hand on a service revolver, a fact some courts seem willing to consider important.

214 This does not mean the officer must simply refrain from acting entirely and let the suspect go free. The officer can continue surveillance or take other steps not implicating the fourth amendment in order to develop reasonable suspicion that would justify a stop.

215 See Burkoff, "Pretext Search Doctrine," supra note 177, at 549 ("Not only is fourth amendment doctrine threatened, the whole fabric of law is threatened, when the law permits-even encourages-the state to legitimize its otherwise unconstitutional acquisition of evidence on the basis of a lie.").

216 See Escobedo v. Illinois, 378 U.S. 478 (1974). 
drawing difficulties. ${ }^{217}$ But the proposed test for defining a seizure does not share those drawbacks. Unlike the focus test, difficult determinations as to the precise level of suspicion that the individual is involved in criminal activity are unnecessary. Rather, constitutional protections are triggered at a single, clearly delineated point: when police initiate contact with a person to discuss his or her involvement in criminal activity. A court may also hesitate to adopt the proposed test because it actually believes the fiction of the Mendenhall-Royer test-that in many police-citizen encounters, a reasonable person would feel free to leave. Such a belief seems unlikely, however, in light of the nearly unanimous agreement to the contrary, even by proponents of the test. ${ }^{218}$

Courts may also believe that a per se rule deprives police of needed flexibility in dealing with the myriad situations represented by police-citizen encounters. ${ }^{219}$ However, if the focus is limited to encounters initiated to investigate the individual's involvement in criminal activity, ${ }^{220}$ the Terry standard itself provides the necessary flexibility. Only reasonable suspicion is required to initiate these encounters. It is not at all obvious why a police officer requires the flexibility to question individuals the officer believes may be involved in criminal activity when the officer's suspicion is below the level of reasonable suspicion. ${ }^{221}$ Being faithful to the fourth amendment's proscription against unreasonable searches and seizures requires denying police officers the flexibility to interfere with a citizen's right to be left alone in the absence of objective justification, or reasonable suspicion, for such interference. ${ }^{222}$ The true need for flexibility is not in making the stop, but in dealing with possible developments following the initial approach. Present interpretations of the scope of permissible police conduct in the course of executing investigative detentions provide this flexibility.

Of course, courts may be unwilling to recognize the "evil" in officers requesting "cooperation" from citizens simply because those citizens happen to be suspected of criminal activity, may be

217 Miranda v. Arizona, 384 U.S. 436 (1966); see also Beckwith v. United States, 425 U.S. 341 (1976).

218 See supra notes $141-42$ and accompanying text.

219 United States v. Berryman, 717 F.2d 651, 661 (1st Cir. 1983)(Breyer, J., dissenting), rev'd, 717 F.2d 650 (1st Cir. 1983)(en banc)(adopting reasoning of dissenting opinion of panel).

220 See supra notes $170-80$ and accompanying text.

221 See Burkoff, "Non Investigatory Police Encounters," supra note 205, at 703-14 ("[T] he value of ["non-investigatory encounters] has been greatly overestimated, and the harms ... greatly underestimated.").

222 Berryman, 717 F.2d at 659. 
unwilling to discard years of precedent despite its lack of clarity, and may be reluctant to make what is perceived to be a change in a seminal case such as Terry. At least a partial answer is that it is the Mendenhall-Royer test that is not true to the Court's opinion in Terry. ${ }^{223}$ The line for what constituted a seizure drawn by the Court in Terry was that "whenever a police officer accosts an individual and restrains his freedom to walk away, he has seized' that person."224 Moreover, the Terry Court recognized that the restraint could be accomplished not only by physical force but also by a show of authority. ${ }^{225}$ In Mendenhall, Justice Stewart converted the detention test of Terry to the "reasonable person" test. That an individual can in fact be restrained-accosted by an officer who has no intention of letting them leave-but not seized for fourth amendment purposes demonstrates that the Mendenhall-Royer test is underinclusive as a trigger for fourth amendment protections.

Even if the proposed test is viewed as overinclusive in that it will classify as seizures cases in which an officer approaches an individual to investigate that individual's involvement in criminal activity but would let the individual decline and walk away, and the individual truly feels free to do so, the test is justified by the experience with Mendenhall-Royer. ${ }^{226}$ Of course, a bright line rule drawn in

223 See Greenberg, supra note 17, at 68; Note, "Reformulating Seizures" supra note 17, at 1496.

224 Terry, 392 U.S. at 16.

225 Id. at 19 n.16.

226 As Professor LaFave has stated:

Fourth Amendment doctrine, given force and effect by the exclusionary rule, is primarily intended to regulate the police in their day-to-day activities and thus ought to be expressed in terms that are readily applicable by the police in the context of the law enforcement activities in which they are necessarily engaged. A highly sophisticated set of rules, qualified by all sorts of ifs, ands, and buts and requiring the drawing of subtle nuances and hairline distinctions, may be the sort of heady stuff upon which the facile minds of lawyers and judges eagerly feed, but they may be "literally impossible of application by the officer in the field."

If the rules are impossible of application by the police, the result may be the sustaining of motions to suppress on Fourth Amendment grounds with some regularity, but this can hardly be taken as proof that "the people" are "secure in their persons, houses, papers, and effects, against unreasonable searches and seizures." Rather, that security can only be realized if the police are acting under a set of rules which, in most instances, makes it possible to reach a correct determination beforehand as to whether an invasion of privacy is justified in the interest of law enforcement. In short, "the understandable temptation to be responsive to every relevant shading of every relevant variation of every relevant complexity" must be resisted or else the result may be "a fourth amendment with all of the character and consistency of a Rorschach blot."

LaFave, “' 'Case by Case Adjudication' Versus 'Standardized Procedures': The Robinson Dilemma," 1974 Sup. CT. REv. 127, 141-42 (1974).

The cases discussed in Section IIIB supra demonstrate that the difficulty in applying the Mendenhall-Royer test has resulted in a fourth amendment with all the character and consistency of a Rorschach blot on the issue of when an officer has seized a citizen. 
favor of suspects risks being labeled a prophylactic rule and being criticized as not being a true gauge of when unconstitutional behavior has occurred. In Professor LaFave's terminology, ${ }^{227}$ it arguably is like telling the police they cannot go beyond mile seven, but placing the seven mile signpost at mile six to make sure the police do not exceed the true seven mile mark.

In the case of the "purpose of the stop" test suggested here, however, this situation does not exist. Rather, the bright line rule is an attempt to place the seven mile signpost precisely at mile seven. At present, that signpost is at mile eight. Police are told they cannot "seize" an individual without reasonable suspicion, but the standard for when a seizure occurs-when a reasonable person would not feel free to walk away-is applied in an artificial fashion that permits police to go beyond the point at which a reasonable person in fact would no longer feel free to walk away. In virtually every case, that point is when the officer approaches the individual and initiates the encounter. Thus, the purpose of the stop test more accurately identifies when a seizure has occurred. The test is much less overinclusive than Mendenhall-Royer is underinclusive and, thus, errs on the side of providing protection for citizens' rights. Moreover, although some may argue that the proposed test is overinclusive and fails to strike the appropriate balance between the interests of the citizens and the state, it must be remembered that police encounters with suspects are not being eliminated or found per se unlawful under the proposed standard. Rather, all that is required is objective justification for the intrusion on a citizen's liberty.

\section{Conclusion}

At a time when legal fictions are viewed skeptically, it is curious that one of the most cherished rights of citizens is being determined by a legal fiction. Hopefully, as state courts increasingly provide greater protections for their citizens than that provided by the United States Supreme Court, ${ }^{228}$ those courts will look carefully at

However, the Supreme Court seems not to appreciate this. See Michigan v. Chesternut, 43 Crim. L. Rptr. (BNA) 3077, 3079 (U.S. S. Ct. June 13, 1988)(objective MendenhallRoyer test allows officers to determine in advance whether their conduct will constitute a seizure).

227 LaFave, "The Fourth Amendment in an Imperfect World: On Drawing 'Bright Lines' and 'Good Faith,' " 43 U. PrTT. L. REv. 307, 359-60 (1982).

228 Collins, "Reliance on State Constitutions-Away From A Reactionary Approach," 9 Hastings Const. L.Q. 1 (1981); Collins, Galie, \& Kincaid, "State High Courts, State Constitutions, and Individual Rights Litigation Since 1980: A Judicial Survey," 13 HasTINGS CoNST. L.Q. 599 (1987); Kelman, "Rediscovering the State Constitutions' Bill of Rights," 27 Wayne L. REv. 413 (1981); Linde, "First Things First: Rediscovering the 
how the liberty rights of their citizens are being decided and discard the fiction of the Mendenhall-Royer test in favor of a test which more realistically determines the seizure question. ${ }^{229}$ In Adamson v. Califormia, ${ }^{230}$ Justice Frankfurter noted that "decisions of this Court do not have equal intrinsic authority."231 In light of the lack of analysis involved in adopting the Mendenhall-Royer test, and the inconsistent results of lower courts applying the test, it should be clear that the intrinsic value of Mendenhall and Royer is not great, and state courts should be willing to analyze for themselves the appropriate test for determining when their citizens are entitled to constitutional protection during encounters with police officers.

States' Bill of Rights," 9 U. BaLt. L. Rev. 379 (1980); Pollock, "The State Constitutions as Separate Sources of Fundamental Rights," 35 RUTGERs L. REv. 707 (1983); Sedler, "The State Constitutions and the Supplemental Protection of Individual Rights," 16 Toledo L. Rev. 465 (1985); Williams, "State Constitutional Law Processes," 24 WM. \& MARY L. REV. 669 (1983).

229 See Dix, supra note 6, at 870 (expressing the view that the development of a consistent and independent approach to the seizure determination by state courts is unlikely due to the "widespread assumption that Supreme Court approaches are presumptively appropriate.").

230332 U.S. 46 (1947).

231 Id. at 59. 